Journal Of Environmental Management

February 2015, Volume 149 Pages 85-96

http://dx.doi.org/10.1016/j.jenvman.2014.10.018

http://archimer.ifremer.fr/doc/00255/36598/

(c) 2014 Elsevier Ltd. All rights reserved.

\title{
A systematic review of socio-economic assessments in support of coastal zone management (1992-2011)
}

\author{
Le Gentil Eric ${ }^{1,{ }^{*}}$, Mongruel Rémi ${ }^{2}$
}

${ }^{1}$ Univ Bretagne Occidentale, UMR AMURE M101, Inst Univ Europeen Met, F-29280 Plouzane, France.

2 IFREMER, UMR AMURE M101, Unite Econ Maritime, F-29280 Plouzane, France.

* Corresponding author : Eric Le Gentil, tel.: +33 (2) 984987 77; fax: +33 (2) 98498609 ;

email address : eric.legentil@univ-brest.fr

Remi.Mongruel@ifremer.fr

\begin{abstract}
:
Cooperation between the social and natural sciences has become essential in order to encompass all the dimensions of coastal zone management. Socio-economic approaches are increasingly recommended to complement integrated assessment in support of these initiatives. A systematic review of the academic literature was carried out in order to analyze the main types of socio-economic assessments used to inform the coastal zone management process as well as their effectiveness. A corpus of 1682 articles published between 1992 and 2011 was identified by means of the representative coverage approach, from which 170 were selected by applying inclusion/exclusion criteria and then classified using a content analysis methodology. The percentage of articles that mention the use of socio-economic assessment in support of coastal zone management initiatives is increasing but remains relatively low. The review examines the links between the issues addressed by integrated assessments and the chosen analytical frameworks as well as the various economic assessment methods which are used in the successive steps of the coastal zone management process. The results show that i) analytical frameworks such as 'risk and vulnerability', 'DPSIR', 'valuation', 'ecosystem services' and 'preferences' are likely to lead to effective integration of social sciences in coastal zone management research while 'integration', 'sustainability' and 'participation' remain difficult to operationalize, ii) risk assessments are insufficiently implemented in developing countries, and iii) indicator systems in support of multi-criteria analyses could be used during more stages of the coastal zone management process. Finally, it is suggested that improved collaboration between science and management would require that scientists currently involved in coastal zone management processes further educate themselves in integrated assessment approaches and participatory methodologies.
\end{abstract}




\section{Highlights}

- A review of the literature on socio-economic assessments in support of CZM was carried out. Socio-economic assessments were included in only $10.1 \%$ of CZM papers. Surveys, monetary valuation, scenarios, and ecosystem services are the most frequently used approaches. Risk and uncertainty assessments are insufficiently implemented in developing countries. Some assessment methods should be used during more stages of the overall CZM process.

Keywords: Integrated coastal zone management, Integrated assessment, Socio-economic assessment, Systematic review 


\section{Introduction}

Managing sustainability in coastal zones is usually referred to as Integrated Coastal Zone Management (ICZM). Although the exact meaning of ICZM may be debated, in broad terms it is intended to deal with conflicts between economic demands and protection of the environment in a given coastal area (Portman and Thunberg, 2011). One of the most popular definitions of ICZM is given by Cicin-Sain and Knecht (1998), who refer to it as "a continuous and dynamic process by which decisions are made for the sustainable use, development, and protection of coastal marine areas and resources" (p. 279). According to these authors, ICZM is "multipurpose oriented: it analyzes implications of development, conflicting uses, and interrelationships among physical processes and human activities, and it promotes linkages and harmonization between sectoral coastal and ocean activities" (Cicin-Sain and Knecht, 1998, p. 41).

The ICZM process thus differs significantly from the "coastal area management" practiced in the late 1960s, which was a set of sectoral policies concerning one or a few uses and carried out only onshore (Vallega, 1999). The geographic scale on which ICZM is applied is essentially set by the extent of the issues it is being used to address (Clark, 1997); since the mid-1990s, this process has promoted the management of conflicting uses and ecosystems on a holistic level, converging with an ecosystems approach (Forst, 2009). Viewed today as the key paradigm for sustainable development of coastal areas (Billé, 2008), ICZM is becoming an operational model of environmental governance in which stakeholders and public participation are key components of successful implementation (Fletcher, 2003).

ICZM became popular in the decision-making sphere following the publication of Agenda 21, adopted during the 1992 United Nations Conference on Environment and Development held in Rio de Janeiro, whose chapter 17 was entirely dedicated to the oceans and coastal areas. Under the title "Integrated management and sustainable development of coastal and marine areas, including exclusive economic zones," the first section of that chapter provides a program for achieving sustainable development in the coastal zones, stressing the need to improve the knowledge used for management purposes and emphasizing the necessity of developing socio-economic and environmental indicators. ${ }^{1}$ This recommendation highlights the need to improve our knowledge of coastal physical systems and uses by drawing on information from both the natural and social sciences (Cicin-Sain, 1993).

Olsen $(1993,2002)$ has described the coastal zone management program (CZM program or ICZM policy cycle) as a process made up of five steps: issue identification and assessment (step 1); program preparation (step 2); formal adoption and funding (step 3); implementation (step 4); and evaluation (step 5). Scientific knowledge is mainly brought in during steps 1 and 5. Integrated Assessment (IA), being an approach that seeks to involve all disciplines in policy-relevant assessment (Harremoës and Turner, 2001), provides a useful framework for informing CZM initiatives, whatever their degree of implementation (Fig. 1). IA consists in combining, interpreting, and communicating knowledge from diverse scientific disciplines in such a way that the whole set of cause-effect interactions of a problem can be evaluated from a synoptic perspective (Rotmans and Dowlatabadi, 1997). In its fully developed form, IA is "an iterative participatory process that links knowledge (science) and action (policy) regarding complex ... issues ..." (van der Sluijs, 2002, p. 250).

\footnotetext{
${ }^{1}$ See in particular paragraph 17.8 of Agenda 21.
} 


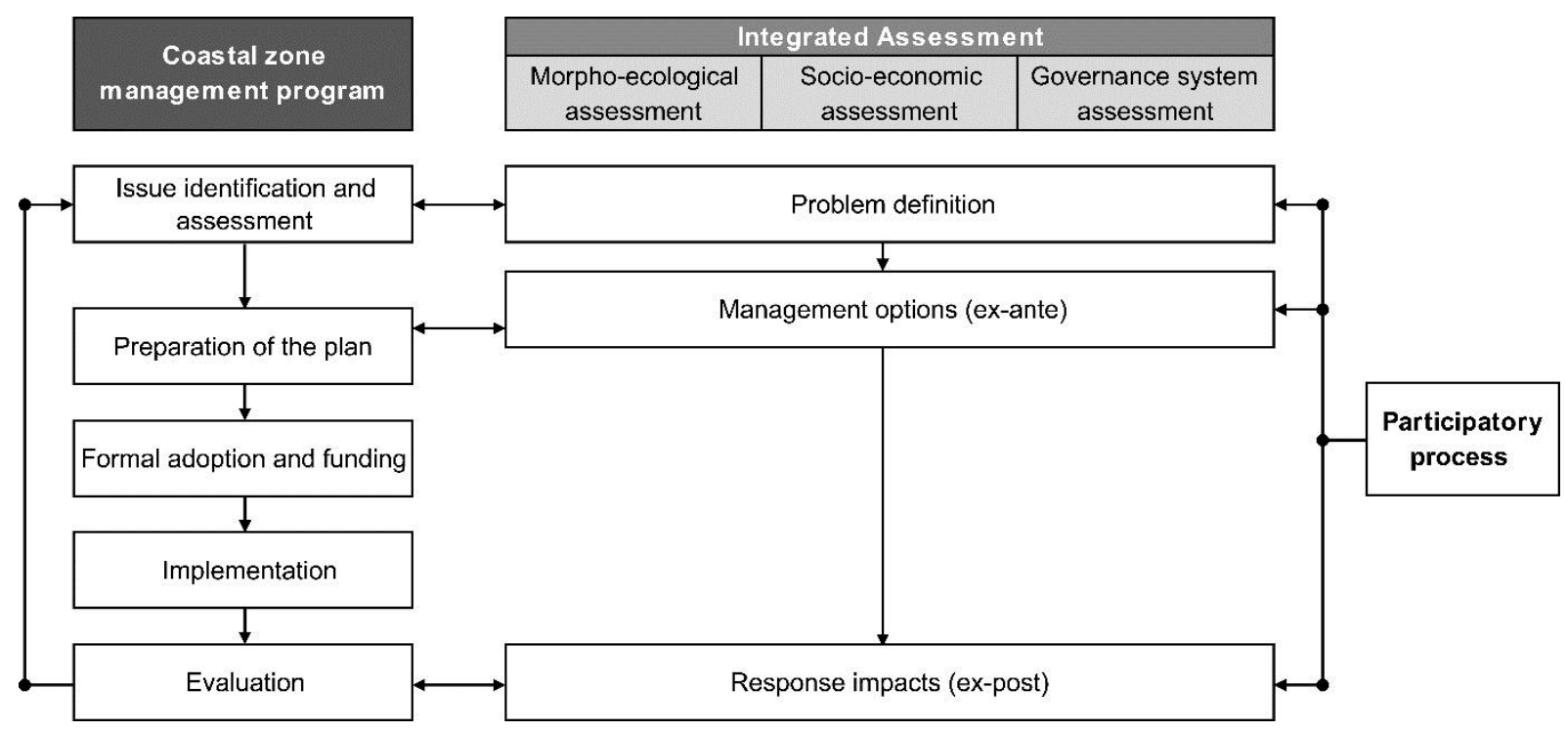

Fig. 1. Main objectives of the integrated assessment used to inform the different steps of a coastal zone management program (our own figure, developed from Olsen, 2002, van der Sluijs, 2002, and Roca, 2008)

The first advantage of IA is that it defines a problem by drawing on current, policy-relevant knowledge. Secondly, IA can help to identify and evaluate specific management options. Thirdly, it may be used for assessing response impacts on coastal problems once management initiatives have been implemented. In this context, cooperation between the social and natural sciences has proved to be helpful for analyzing all the dimensions of improved CZM; socio-economic approaches in particular are increasingly needed to better understand the linkages and interdependencies between natural and anthropogenic systems in coastal areas (Cooper and McLaughlin, 1998; Bowen and Riley, 2003; Ban et al., 2009; Nobre, 2011).

Examples of research studies that have used or produced socio-economic assessments in support of CZM are abundant. These socio-economic assessments address a variety of goals, issues, and interactions and may use a wide range of tools, methodologies, information, and analytical frameworks. It thus seems worthwhile to carry out an analysis of socio-economic assessments in support of CZM through a systematic literature review. However, to our knowledge, only three literature reviews have attempted to explore this research field. Cooper and McLaughlin (1998) analyze the "contemporary multidisciplinary approaches to coastal classification and environmental risk analysis" (p. 512) in terms of scale of application, variables included, mode of analysis, mode of presentation, and the nature of the risks being assessed. Carneiro (2011) explores "the evidence of the impacts of marine management interventions on human development and well-being reported in marine management literature in the past two decades" (p. 351). His study addresses peer-reviewed literature dealing with fisheries, aquaculture, marine conservation, and CZM in terms of methodologies used, human development dimensions considered, and results reported. Nobre (2011) reviews management instruments to address coastal zone problems and of some research areas to support management. Although very interesting, these reviews consider only some specific uses of socio-economic information, such as the problem definition step of CZM (Cooper and McLaughlin, 1998) and the impact assessments of management initiatives (Carneiro, 2011; Nobre, 2011). All these studies take the form of a narrative literature review.

This paper presents a systematic review of the extensive body of academic writing from the period 1992-2011 concerning the socio-economic assessments used in support of CZM. The aim of our study is to further analyze the issues addressed by socio-economic assessments as well as the kind of assessment methods and tools used in the successive steps of the CZM process. The paper is 
structured as follows: Section 2 defines the data sources and explains the systematic review methodology. Section 3 highlights the main findings obtained from the content analysis approach. Finally, Section 4 discusses the influence of the political context on socio-economic assessments and the contribution of the social sciences to improved science-management integration.

\section{Materials and methods}

A systematic review was performed in order to analyze how socio-economic approaches are envisaged and addressed in the dedicated CZM literature. Unlike traditional or narrative literature reviews, such as the expert point of view or position papers on a particular topic (e.g. Carneiro, 2011), the systematic review is a process through which a sample of works/studies is methodically chosen, the targeted information is extracted, and the results reported with transparency about the methods used in each step (Hunt, 1997).

According to Booth et al. (2012), the literature review process generally comprises four steps: search, appraisal, synthesis, and analysis. Appraisal or quality assessment of the selected documents has not been included in our approach because the goal pursued in this step is to "exclude poor-quality studies" (Booth et al., 2012, p. 29). Consequently, the three major analytical steps were used in this study to identify peer-reviewed literature that uses socio-economic approaches to inform the CZM process: the search and selection process, content analysis, and statistical analysis (Fig. 2).

\subsection{The search and selection process}

The first step, the search and selection process, falls into two distinct phases. Phase 1 constructed a reference population of scientific publications in which we could find relevant literature. During phase 2 , the most relevant documents from this population were selected on the basis of several criteria defined on the basis of our objectives. Due to the abundance of materials concerning CZM, it was decided to study only peer-reviewed scientific literature.

As it was not possible to study all peer-reviewed papers on CZM, the representative coverage approach (Cooper, 1988) was adopted in phase 1. This consists in applying the review process to a population of works that are considered to be "broadly representative of many other works in a field" (Cooper and Hedges, 2009, p. 5), so we deliberately confined our research to the examination of a single database, Web of Science (WoS), which references the vast majority of journals dealing with CZM (e.g. Ocean \& Coastal Management, Coastal Management, Journal of Coastal Research, Journal of Coastal Conservation, Marine Policy, and Coastal Engineering). The search for documents was carried out at the beginning of January 2013 and sought to cover all English-language material from 1992 to 2011, with the start date corresponding to the 1992 United Nations Conference on Environment and Development (Rio summit), when ICZM became a generally accepted referential for coastal zone policies in most countries around the world (Cicin-Sain, 1993). The choice was made to conduct database searches with a few keywords judged sufficiently broad to capture a vast diversity of expressions relative to the issue of CZM. Our review is thus based on searches with the terms "coastal management" or "coastal zone management" in documents" keywords, abstract, or title: the searches produced 1682 studies published over the past 20 years. Searches were done on all journals available in the WoS database (including conference proceedings published in peer-reviewed journals), regardless of the disciplinary field. We did not employ queries on specific coastal issues or coastal uses so as to avoid introducing bias in the results.

In phase 2, the abstracts and titles of this total population of 1682 peer-reviewed papers were read in order to select the final sample based on inclusion/exclusion criteria. The inclusion criteria were 
conformity with one (or more) of the objectives of the IA identified in the first section (see Fig. 1) and the use of quantitative socio-economic data sets (i.e. data describing human behavior). We excluded from the analysis literature reviews, conceptual articles, book chapters, papers which contained only landuse and demographic information, and papers dedicated to high seas management. This selection process aimed at getting a homogeneous sample, meaning one composed of studies similar enough to be categorized. 174 documents corresponding to our inclusion criteria were identified and four duplicates were removed, leaving 170 articles for evaluation (Supplement 1). Duplicates correspond to articles that employ case studies drawn upon (using the same data and methodologies) in other papers of our sample.

Step 1. Search and selection process

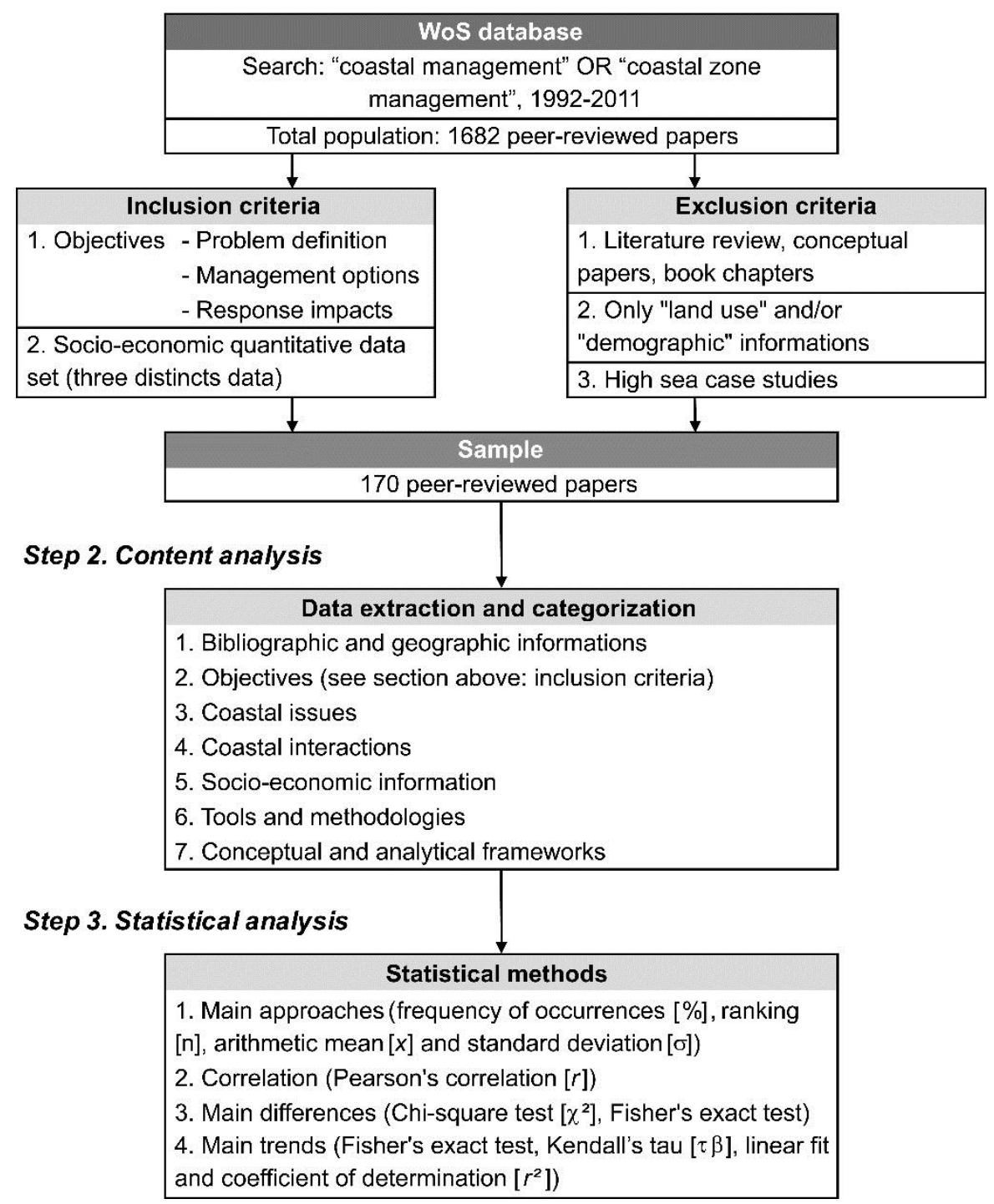

Fig. 2. The systematic review approach

\subsection{Content analysis}

We carried out a content analysis on the chosen references in order to categorize them. "Content analysis [is] a technique of measurement applied to text" in which the coding is an instrument of measurement (Markoff et al., 1975, in Franzosi, 2008, p. xxviii). It is a data collection method used to identify trends and changes in content (Franzosi, 2008). All the documents selected were classified 
using a number of categories: the main objectives of the study in terms of the IA framework (problem definition, management options, and response impacts); coastal issues; coastal interactions; socioeconomic information; tools/methodologies; and analytical/conceptual frameworks (Fig. 2). As a great variety of coastal issues, tools/methods, and socio-economic information is commonly analyzed and used in these studies, we initially noted all the terminologies employed and then grouped them into more generic categories (Supplement 2). Unlike the other categories, analytical and conceptual frameworks were identified on the basis of the author's terminology in the title and abstract. In addition, we considered bibliographical and geographical information: author name(s), journal name, publishing year, location of case study (country, region), and disciplinary approach (interdisciplinary or monodisciplinary). An iterative checking process was used to validate the classification categories and subcategories.

\subsection{Statistical analysis}

Several statistical methods were used to synthesize the results of the content analysis. These results are expressed in frequency of occurrences, i.e. number of items as a percentage of the total number of publications in the sample $(n=170)$ or in the various defined categories. The statistical values obtained were not considered for themselves, but for what they represent. Differences among the categories and general trends were identified using various statistical methods.

Temporal trend analyses were calculated using Kendall's tau, as it presents some advantages over the Spearman coefficient, particularly when data are tied. For qualitative data, differences between categories were tested using either a Chi-Square test $(2 \mathrm{X} 2,2 \mathrm{XN})$ or Fisher's exact test when samples were too small (any expected frequencies < 5). To characterize other data, the arithmetic mean, standard deviation, Pearson correlation coefficient and coefficient of determination were used.

The results of the Chi-Square test $(2 X 2,2 X N)$, Fisher's exact test, Pearson correlation coefficient, and Kendall's tau were considered statistically significant when the probability level ( $p$-value) was smaller than the chosen significance level of .05. Results were considered non-significant when $p>.10$, and results with $.05<p \leq .10$ were reported as borderline cases (Rice, 1989).

\subsection{Principal limitations}

Interpretations based on the results of this methodology are limited by several factors. Firstly, WoS indexing practices can limit the reliability of the findings. Secondly, the representative coverage approach is open to the arbitrary definition of inclusion criteria by the review's authors (Cooper, 1988). Thirdly, there is a language of publication bias, since only English-language papers were reviewed. Lastly, potential for researcher bias exists since only one coder was used (Allen and Reser, 1990 in Franzosi, 2008). In this context, scientific transparency about the method used is essential for a reader to be able to discuss an author's results (Hunt, 1997).

The list of selected socio-economic studies informing CZM process is thus not exhaustive and further materials undoubtedly exist (in journals not indexed in WoS and in unpublished reports). For practical reasons, we have limited our systematic review to academic literature, as did Laurans et al. (2013) in their analysis of the economic valuation of the use of ecosystem services. However, the sample in our study covers a wide range of coastal issues and features a variety of socio-economic approaches. The aim of our study being to understand how socio-economic assessments are used for CZM, this sample permits us to draw representative conclusions on the topic. 


\section{Results}

Subsection 3.1 presents the main characteristics of the peer-reviewed literature dedicated to CZM. Subsection 3.2 highlights the main conceptual and analytical frameworks used for socio-economic assessments, along with trends in their adoption. Subsection 3.3 analyzes the attributes of socioeconomic assessments. Subsection 3.4 deals with the link between the level of development and the types of coastal problem which are taken into account for management. Subsection 3.5 examines the main differences between articles with respect to the objectives assigned to socio-economic assessments.

\subsection{Bibliographical and geographical characteristics}

Our systematic review retrieved a total population of 1682 papers dealing with CZM from the WoS, from which a sample of 170 papers $(10.1 \%)$ provided socio-economic assessments that were used to inform the CZM process and were based on a quantitative data set. These 170 papers were published in 49 international journals; about half of them (48\%) appeared in the Journal of Coastal Research, Ocean \& Coastal Management, and Coastal Management (Supplement 3). The total population of the sample of socio-economic assessments presents a fairly similar distribution across the types of journal where they are published, although socio-economic assessments appear to be slightly less well represented in marine sciences journals. However, the geographical distribution of studies displays contrasting profiles.

A) Sample $(n=170)$

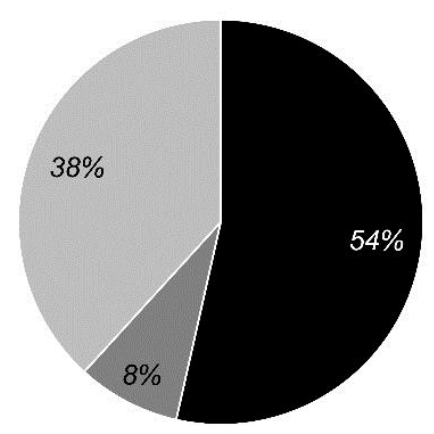

B) Population $(N=1682)$

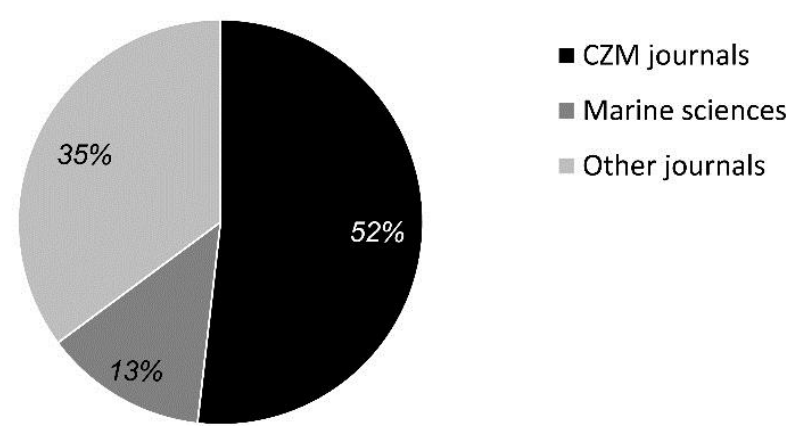

Fig. 3. Comparison between sample (A) and population (B) with respect to the journals represented. CZM journals are Ocean \& Coastal Management, Coastal Management, Journal of Coastal Research, Journal of Coastal Conservation, Marine Policy, and Coastal Engineering. Marine sciences journals are other journals whose titles refer to the sea or coastal zone.

From the total population of 1682 papers, 1533 case studies with a clear geographical location were identified and used for comparison with the sample. Socio-economic assessments in support of CZM are mostly performed in northwestern Europe, followed by Asia, southeastern Europe (including the Mediterranean and Black Sea), and South America (including the Caribbean Sea and Gulf of Mexico). Surprisingly, North America, which provides the second largest amount of coastal zone papers, is the less documented region together with the Australasia as regards socio-economic assessments (Supplement 3). One possible explanation is that North American scholars and managers are more 
reluctant to carry out assessments with poor observable facts and data, as we know that socio-economic information on coastal zones remains very sparse all over the world. ${ }^{2}$
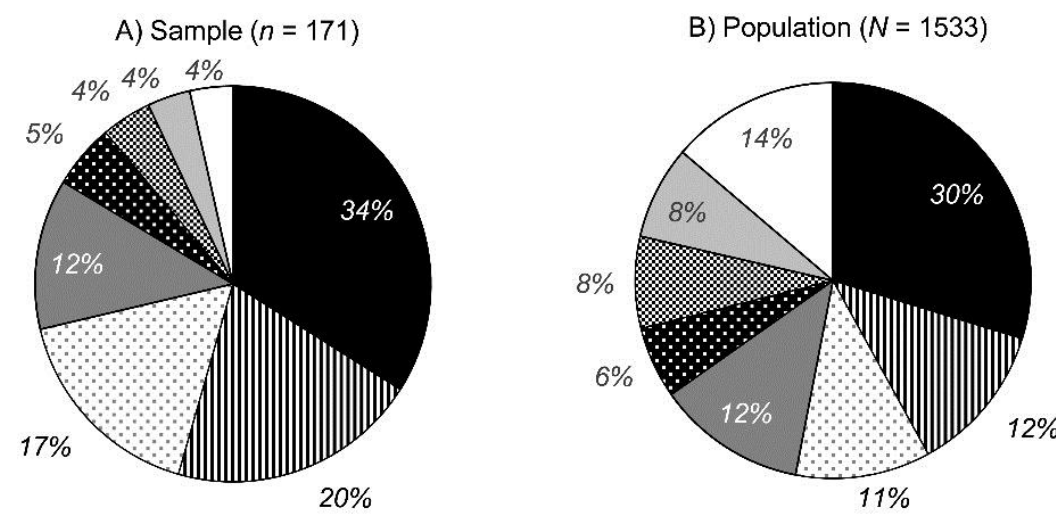

\author{
- Northwestern Europe \\ m Asia \\ $\square$ Southeastern Europe \\ $\square$ South America \\ Africa \\ ख Middle East, Indian subcontinent \\ $\square$ Australasia, Pacific islands \\ $\square$ North America
}

Fig. 4. Comparison between sample (A) and population (B) with respect to the geography of case studies.

\title{
3.2. The rise and decline of conceptual frameworks
}

The second aspect explored here is the context-dependence of socio-economic assessments for CZM. We first examine the main conceptual/analytical frameworks that have emerged and developed in the CZM field as well as those in decline, in the international policy and scientific contexts (3.2.1). Next we point out the discrepancy between the analytical frameworks claimed and actually used (3.2.2).

\subsubsection{Emerging and declining concepts in the international policy and scientific contexts}

We mentioned in the introduction that socio-economic assessments were increasingly needed for CZM; our review demonstrates that they are also produced increasingly often (Fig. 5). Since the Earth Summit held in Rio de Janeiro in 1992 (United Nations Conference on Environment and Development), the use of socio-economic assessments in support of CZM has become widespread. It is a gradual trend, without any very sudden breaks that might indicate the overt influences of international environmental policies, though we may suppose that they have had a positive albeit tacit effect on CZM research, via science policies and funding.

\footnotetext{
2 This result is also at odds with the belief that WoS is a database that largely references peer-reviewed literature dealing with North American case studies, unlike Scopus which references mainly European case studies (Falagas et al., 2008).
} 


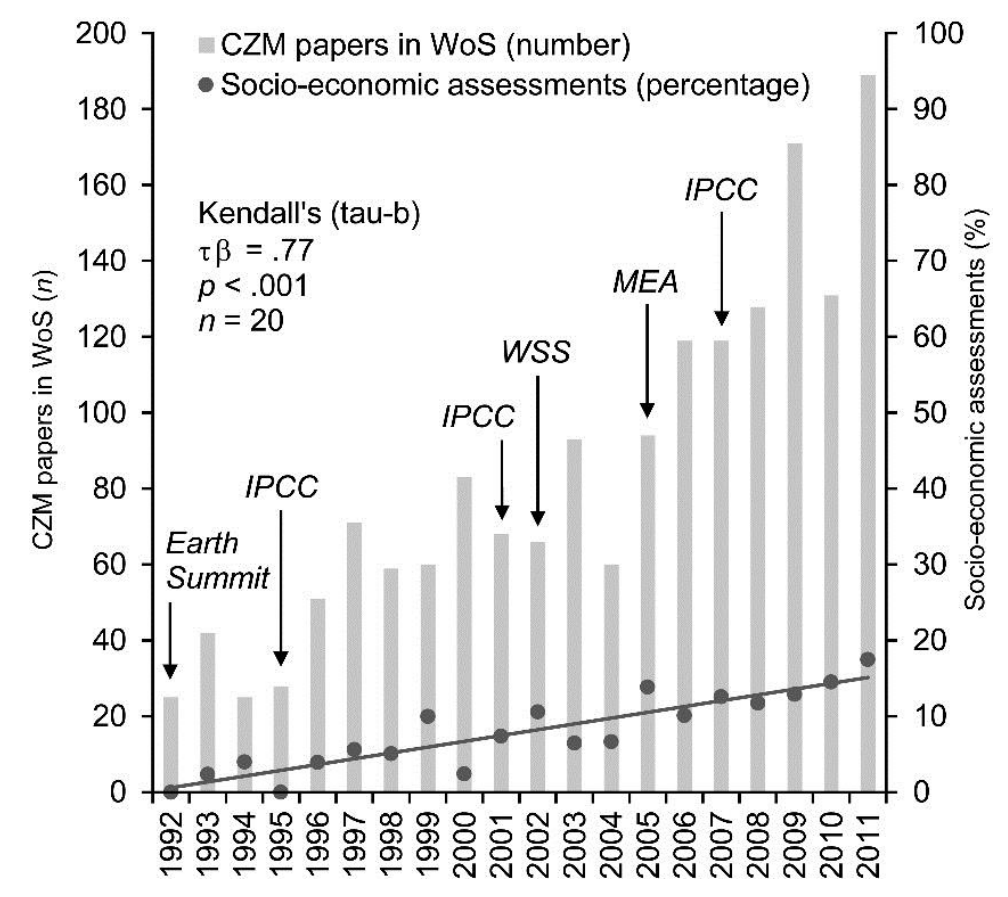

Fig. 5. Evolution of socio-economic assessments $(n=170)$ from 1992 to 2011 . Values expressed as a percentage of total number of (identified) papers dealing with CZM in WoS $(n=1682)$. Background events: 1992, Earth Summit (United Nations Conference on Environment and Development in Rio de Janeiro); 2002, Johannesburg World Summit of Sustainable Development (WSSD); 2005, Millennium Ecosystem Assessment (MEA, 2001-2005); 1995, 2001, and 2007, IPCC Assessment Reports (Intergovernmental Panel on Climate Change). The existence of a trend was tested using Kendall's tau (significant positive trend). The best fit is also shown (linear fit: $y=0.7659 x-0.1633, r^{2}=.81$ ).

The influences are a little more manifest if we look at the evolution of the main analytical and conceptual frameworks used for socio-economic assessment, based on the expressions used by the authors in their titles and abstracts. ${ }^{3}$ Over the whole period (1992-2011), by far the most popular concept adopted for implementing the socio-economic assessment of CZM is "integration," followed by "sustainability" and "perceptions, opinions," while the most uncommon are "vulnerability, risk," "DPSIR-PSR," and "carrying capacity" (Supplement 3). In order to identify the main trends, we split our reference period into three shorter phases on the basis of the international policy and scientific calendars (1992-2001, 2002-2006, and 2007-2011). When we compare these periods, it appears that the concept of "sustainability" is becoming more and more popular in the literature, along with "integration," with "ecosystem services" and "vulnerability, risk" appearing to a lesser extent (Fig. 6, Supplement 3). This is doubtless due to the Rio Conference (1992) and Johannesburg World Summit on Sustainable Development (2002), which have greatly popularized the concepts of "sustainability" and "integration" and stressed their importance, while the scientific working reviews of the IPCC (Assessment reports of 1990, 1995, 2001, and 2007) and MEA (2001-2005) have probably contributed to the permanent presence of the concepts of "vulnerability, risk" and "ecosystem services" in the international scientific and policy arenas.

\footnotetext{
${ }^{3}$ These results are based purely on the authors' terminologies, not on our own interpretation.
} 


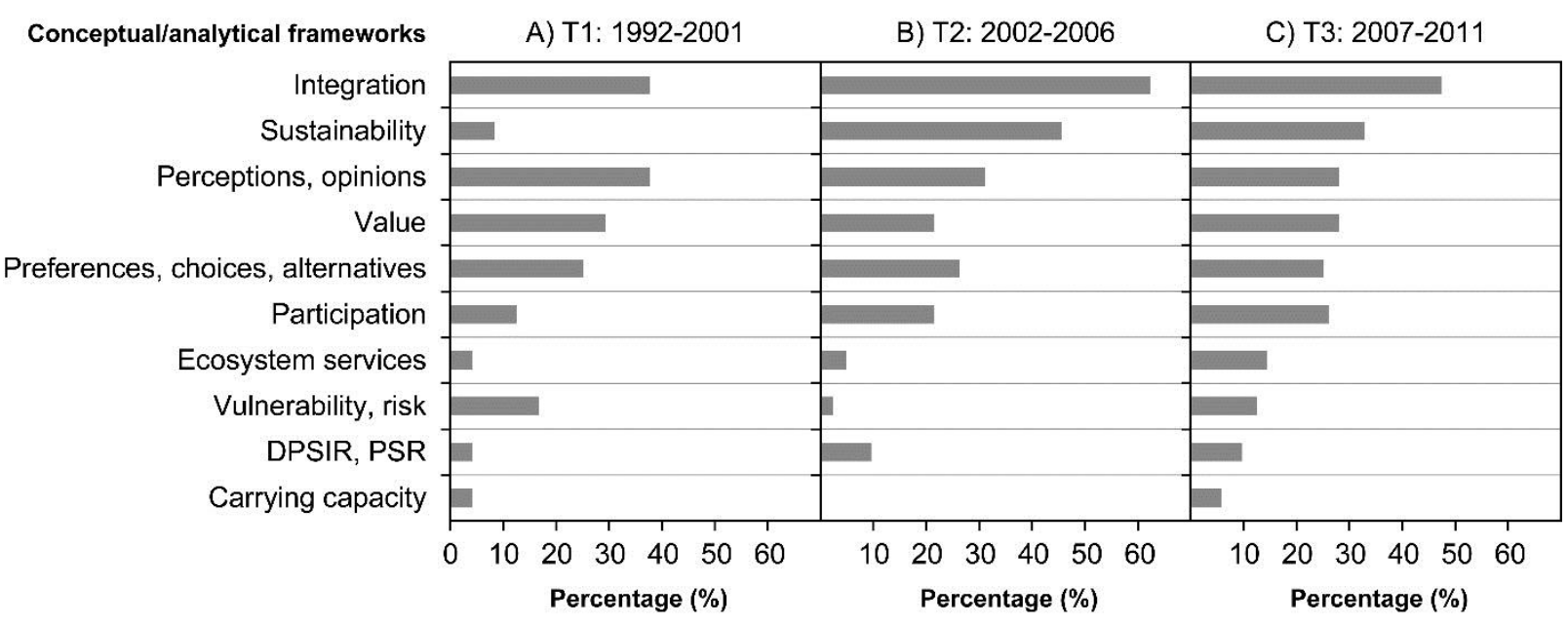

Fig. 6. Trends for the ten most popular conceptual/analytical frameworks (expressed as a percentage of the total number of publications per period): A) 1992-2001 ( $n=24)$, B) 2002-2006 $(n=42)$ and C) 2007-2011 $(n=104)$.

The most surprising of these results is the lack of a clear (increasing) trend for "DPSIR, PSR" (Fig. 6, Supplement 3). The Organization for Economic Cooperation and Development (OECD) created the "Pressure-State-Response" (PSR) analytical framework in 1993 to help model cause and effect relationships between humans and the environment; it was refined and expanded afterwards to "include the root causes of environmental change and the impacts this change has on ecosystems and on humans" (Bowen and Riley, 2003, p. 303), in an approach described as the "Driver-Pressure-StateImpact-Response" (DPSIR). Widely recommended for supporting CZM and often used for structuring indicator sets, it is more and more frequently employed in conjunction with participatory methods in order to better clarify non-expert knowledge. However, DPSIR does not appear to be a framework that greatly enhances the gathering of socio-economic information about CZM. It seems that the concepts of "value" and "perceptions, opinions" are coming to be used less and less, perhaps because of their gradual replacement in the literature by "ecosystem services (valuation)" and "participation."

\subsubsection{Discrepancies between analytical frameworks claimed and actually used}

Nonetheless, a reference to a conceptual framework does not imply its actual implementation. Many of the authors who explicitly mention "integration," "sustainability," or "participation" rarely use integrated approaches (integrated assessment and/or modeling, system or ecosystem approaches), carry out very few sustainability assessments (with indicator sets), and rarely implement participatory approaches by means of workshops with local stakeholders or focus group meetings (Table 1). By contrast, the concepts of "perception, opinion" are infrequently emphasized in connection with the use of opinion surveys in our selected materials (Table 1). There is a closer correlation between the identification of "risk, vulnerability," "DPSIR, PSR," "carrying capacity," "value," "ecosystem services," and "preferences, choices, alternatives" as conceptual frameworks and their actual implementation by means of specific tools and methodologies, no doubt because these analytical frameworks are less controversial. "Vulnerability, risk" and "ecosystem services," for example, are well defined and have gained broad consensus in the international scientific community, probably as a result of the work of the IPCC and MEA. 
Table 1. Differences between claimed conceptual/analytical frameworks (A) and actually used scientific frameworks (B) (values expressed as a percentage of the total number of publications for the period 1992-2011, $n=170)$.

\begin{tabular}{|l|r|l|r|r|}
\hline $\begin{array}{l}\text { A) Conceptual and analytical } \\
\text { framew orks }\end{array}$ & $\begin{array}{c}\text { Claimed } \\
\text { (frequency) }\end{array}$ & $\begin{array}{l}\text { B) Scientific framew orks } \\
\text { (tools, methods) }\end{array}$ & $\begin{array}{c}\text { Used } \\
\text { (frequency) }\end{array}$ & $\begin{array}{c}\text { Difference } \\
\text { (B - A) }\end{array}$ \\
\hline Integration & $49 \%$ & Integrated approaches & $13 \%$ & $-36 \%$ \\
Sustainability & $33 \%$ & Sustainability assessment (indicators) & $7 \%$ & $-26 \%$ \\
Participation & $23 \%$ & Participatory approaches & $6 \%$ & $-16 \%$ \\
Vulnerability, risk & $10 \%$ & Vulnerability or risk assessment (indicators) & $6 \%$ & $-4 \%$ \\
DPSIR, PSR & $9 \%$ & Pressures-States-Responses indicators & $6 \%$ & $-3 \%$ \\
Carrying capacity & $4 \%$ & Carrying capacity measurement & $4 \%$ & $0 \%$ \\
Value & $26 \%$ & Economic valuation (coastal activites) & $29 \%$ & $2 \%$ \\
Ecosystem services & $11 \%$ & Ecosystem services valuation & $14 \%$ & $4 \%$ \\
Preferences, choices, alternatives & $25 \%$ & Scenario, prospective & $29 \%$ & $4 \%$ \\
Perceptions, opinions & $30 \%$ & Opinion survey & $61 \%$ & $31 \%$ \\
\hline
\end{tabular}

\subsection{Principal attributes of socio-economic assessments}

Socio-economic assessments of CZM are defined by the type of socio-economic information, the tools and methods implemented, the goal of the assessment, the coastal issues addressed, and the kind of coastal interactions to be managed (Table 2).

Table 2. Principal socio-economic information discussed in the selected papers (expressed as a percentage of the total number of papers, $n=170$ ). Note: Totals do not equal $100 \%$ (with the exception of assessment goals) because a study may analyze several coastal issues and coastal interactions and use several tools/methods and different types of socio-economic information. Assessment goals are equal to $100 \%$ because an item that corresponds to "problem definition" and "management options," for example, is only classified as "management options."

\begin{tabular}{|lrr|}
\hline A) Socio-economic information & Frequency & Rank \\
\hline Coastal population & $66 \%$ & 1 \\
Coastal use intensity & $62 \%$ & 2 \\
Opinion, preference & $61 \%$ & 3 \\
Monetary value & $53 \%$ & 4 \\
Coastal activities (economy) & $52 \%$ & 5 \\
Management & $52 \%$ & 5 \\
\hline
\end{tabular}

\begin{tabular}{|lrr|}
\hline C) Assessment goals & Frequency & Rank \\
\hline Management options & $40 \%$ & 1 \\
Problem definition & $39 \%$ & 2 \\
Response impacts & $21 \%$ & 3 \\
\hline & & \\
\hline D) Coastal issues & Frequency & Rank \\
\hline Environmental degradation & $69 \%$ & 1 \\
Coastal economy, livelihood & $64 \%$ & 2 \\
Coastal amenities, w elfare & $46 \%$ & 3 \\
Coastal hazards & $34 \%$ & 4 \\
\hline
\end{tabular}

\begin{tabular}{|lrr|}
\hline B) Tools and methods & Frequency & Rank \\
\hline Survey & $70 \%$ & 1 \\
Monetary valuation & $53 \%$ & 2 \\
Spatial data analysis & $44 \%$ & 3 \\
Trends analysis & $41 \%$ & 4 \\
Scenario, prospective & $29 \%$ & 5 \\
Explanatory modelling & $22 \%$ & 6 \\
Indicators system & $21 \%$ & 7 \\
CBA or CEA & $14 \%$ & 8 \\
Multi-criteria analysis & $9 \%$ & 9 \\
Participatory approaches & $6 \%$ & 10 \\
\hline
\end{tabular}

\begin{tabular}{|lrr|}
\hline E) Coastal interactions & Frequency & Rank \\
\hline ECOL states / SOC impacts & $50 \%$ & 1 \\
SOC / ECOL and ECOL / SOC & $32 \%$ & 2 \\
SOC pressures / ECOL states & $13 \%$ & 3 \\
SOC pressures / SOC impacts & $8 \%$ & 4 \\
\hline
\end{tabular}

The most frequently used socio-economic information concerns coastal populations (Table 2), no doubt because it is readily available. This category encompasses demographic and livelihood data. "Coastal use intensity" is the second most frequent type of information used, and brings together very different 
data (beach frequentation, coast artificialization, aquaculture production, etc.). More generally, all categories of socio-economic information are frequently used, and $94 \%$ of the papers simultaneously make use of 2 or more information types. The mean number of types of information used per paper is $3.45(\sigma=1.29, n=170)$ and the most common combination is "coastal population," "coastal use intensity," "economic value," and "coastal activities" (10\%) (Supplement 3).

One way to obtain quantitative information is via a survey, and this is the most widely used methodology in our sample (socio-economic and opinion surveys) (Table 2). "Monetary valuation" is the second most common, while the least common are "Cost-Benefit Analysis (CBA) or Cost-Effectiveness Analysis (CEA)," "multi-criteria analysis," and "participatory approaches." The last three categories are less frequently used no doubt because they require more information, human and financial resources, and capacity. $90 \%$ of these studies employ 2 or more tools and methods. The mean number of used tools/methods per paper is quite similar to that of the socio-economic information $(\bar{x}=3.21, \sigma=1.46, n$ $=170$ ) and the most common combination is "survey" and "spatial data analysis" (6\%) (Supplement 3 ). The more tools are employed per study, the lower the number of the studies $(r=-.35, p<.05, n=76)$.

Like tools and methodologies, research objectives (assessment goals) are not equally distributed across the three categories defined (Table 2). 39\% of the selected papers deal only with "problem definition," $40 \%$ address the "option response" issue (identification and/or analysis), and only $21 \%$ assess impact management ("response impacts") with respect to specific improvements in the quality of life of coastal populations or associated benefits and resulting changes in the environmental condition of coastal systems.

Of the principal coastal issues, the selected papers focus mainly on the topics of "environmental degradation" (69\%) and "coastal economy, livelihood" (64\%) (Table 2). 89\% address both socioeconomic issues ("coastal economy, livelihood" and/or "coastal amenities, welfare") and environmental ones ("coastal hazards" and/or "environmental degradation") through the study of different forms of coastal interaction between humans (social subsystem: SOC) and marine or coastal ecosystems (ecological subsystem: ECOL). The most common interaction is that between the social impacts of changes and the environmental state of the coastal system (ECOL states / SOC impacts: Table 2). Surprisingly, cross-interactions (SOC / ECOL and ECOL / SOC) are more often investigated than single links between coastal phenomena, such as pressures, and environmental states (SOC pressures I ECOL states). Interactions between coastal uses and coastal populations (SOC pressures / SOC impacts - the effect of beach litter on beach attractiveness, for example) are less often studied.

\subsection{Coastal issues and the level of economic development of the country studied}

Studies conducted on high-income economies are more numerous than those in low- and middleincome economies (Table 3, Supplement 3). This situation reflects differences in research financing between these two groups of countries (UNESCO, 2010). This disparity is also significant when we examine which coastal issues are chiefly studied (Table 3), although it does not exist in the case of the nature of coastal interactions (Table 3). This may be due to the historical prominence of the European and North American science community in CZM research; its ways of understanding coastal interactions are often the same regardless of the specifics of the case study.

The two main differences are the discrepancies between "coastal amenities, welfare" and "coastal hazards" (Table 3). The amenities and welfare of the coastal population are certainly more often studied in high-income countries. This is due to the emergence of the "leisure society" in the sixties (Dumazedier, 1962), which has become more and more oriented toward nature and outdoor recreational activities (Sharma, 2004). By contrast, the lower interest in this issue in the poorest countries is due to the primacy of basic concerns like nutrition needs. When amenities and nature conservation needs are addressed, 
it is often with respect to the attractiveness for tourists of regions where coastal tourism development is rapid and highly dependent on environmental quality (Gormsen, 1997), and where detrimental consequences for sensitive coastal resources and ecosystems can be observed (e.g. Sobhee, 2006).

Table 3. Level of economic development of the country studied with respect to (A) coastal issues and (B) coastal interactions. Coastal issues and coastal interactions are expressed as a percentage of the total number of studies per country income levels. Income levels correspond to the $2011 \mathrm{GNI}$ per capita (formerly GNP per capita). GNI is the "gross national income, converted to U.S. dollars using the World Bank Atlas method, divided by the midyear population" (World Bank, 2013). Low- and middle-income economies have been grouped into a single category in order to get two samples fairly close in size. Differences between $A$ and $B$ were assessed using Fisher's exact test.

\begin{tabular}{|l|c|c|c|c|}
\hline A) Coastal issues & $\begin{array}{c}\text { Coastal amenities, } \\
\text { w elfare }\end{array}$ & $\begin{array}{c}\text { Coastal economy, } \\
\text { livelihood }\end{array}$ & $\begin{array}{c}\text { Environmental } \\
\text { degradations }\end{array}$ & Coastal hazards \\
\hline a. Low and middle income $(n=68)$ & $22 \%$ & $79 \%$ & $78 \%$ & $21 \%$ \\
b. High income $(n=102)$ & $62 \%$ & $53 \%$ & $62 \%$ & $41 \%$ \\
\hline Difference $(\mathrm{a} \neq \mathrm{b})$ & Significant & Significant & Significant & Significant \\
\hline
\end{tabular}

\begin{tabular}{|l|c|c|c|c|}
\hline B) Coastal interactions & $\begin{array}{c}\text { ECO states / } \\
\text { SOC impacts }\end{array}$ & $\begin{array}{c}\text { SOC pressures / } \\
\text { ECO states }\end{array}$ & $\begin{array}{c}\text { SOC / ECO and } \\
\text { ECO / SOC }\end{array}$ & $\begin{array}{c}\text { SOC pressures / } \\
\text { SOC impacts }\end{array}$ \\
\hline a. Low and middle income $(n=67)$ & $51 \%$ & $12 \%$ & $34 \%$ & $4 \%$ \\
b. High income $(n=98)$ & $50 \%$ & $13 \%$ & $31 \%$ & $11 \%$ \\
\hline Difference $(a \neq b)$ & Not significant & Not significant & Not significant & Not significant \\
\hline
\end{tabular}

Coastal hazards are also less often studied in low- and middle-income economies than in the richest countries (Table 3). This is problematic because of the tight linkages between development and social vulnerability to coastal hazards (Ward and Shively, 2012). Coastal populations in the poorest countries are especially vulnerable to extreme weather events, due to "their low physical and financial capacity to withstand economic shocks, their disproportionate dependence on climate-sensitive sectors, and the inherently low capacity of developing country governments to provide social safety nets or invest in basic infrastructure aimed at disaster preparedness and relief" (Ward and Shively, 2012, p. 916). More generally, the scarcity of socio-economic assessments in the area of coastal hazards in low- and middleincome economies may be due to the scarcity of official statistics by comparison with high-income economies, the difficulties of adjusting the data available to the research objective being pursued when official statistics do exist (the lack of correspondence between administrative boundaries and areas at risk, for example), and the substantial human and time resources required to conduct socio-economic surveys in places that are often heavily populated (low-lying areas such as deltas, for example).

In short, there seems to be an imbalance between the richest and poorest countries in the way that socio-economic coastal research is conducted. This imbalance can be explained by the prevalence of certain concerns in only some parts of the world and by the difficulty of generating socio-economic information because of the constraints mentioned above.

\subsection{Socio-economic assessment and integrated assessment objectives}

The uses made of socio-economic information and of tools and methodologies differ significantly depending on the purposes of the assessments (Fig. 7, Fig. 8, Supplement 3). In this section, we analyze the principal differences among the research studies by identifying the data and methods most often employed, following the successive steps of CZM programs. 


\subsubsection{Problem definition}

The "problem definition" step mainly utilizes information regarding "coastal population," "coastal use intensity," "coastal activities," and "monetary value," and tools/methodologies such as "spatial data analysis," "survey," "monetary valuation," and "indicator system," in order to describe the interdependencies and interactions between people and their environment (Fig. 7 and Fig. 8). It is noteworthy that during the problem definition step, information about the existing management system is gathered in no more than $20 \%$ of the papers, which suggests an insufficient attention to institutional change as a complex and dynamic process.

Three questions are commonly raised in order to identify, define, and explain coastal problems in connection with management improvements: how people perceive the quality of their environment; how they utilize and benefit from coastal resources and ecosystem; and how this utilization impacts resources and the ecosystem. Each tool and methodology for socio-economic assessment may be more or less accurate in answering each of these questions.

Surveys, frequently employed to answer the first and second questions, give an overview of the main (perceived) environmental issues (opinion data) (e.g. Morgan, 1999) and assess coastal populations' socio-economic dependence on resources by analyzing the existing links between ecosystem services production, the coastal economy, and human livelihood (e.g. Nogueira de Andrade et al., 2010). Spatial data analysis is more widely used for answering the third question, that is, producing an overview of socio-economic pressures and associated environmental degradation by mapping the geographical distribution of the "coastal population," "coastal use intensity," or "coastal activities," and the corresponding coastal habitat and resources at risk (e.g. Lloret et al., 2008). In some cases, however, it is also employed for comparison of economic activities between different localities for the purpose of diagnosis on a regional scale (e.g. Sarda et al., 2005). Monetary valuation is frequently used in addressing the second and third questions; monetary value estimates are produced in the context of local economic diagnosis, income survey, or amenities and/or ecosystem services valuation (e.g. Samonte-Tan et al., 2007). In the latter case, land use/land cover (spatial data analysis) is often used to generate estimates of the monetary value of ecosystem services in the coastal zone via benefit transfer analysis (e.g. Brenner et al., 2010).

Indicator systems are in common use for "problem definition," but always for addressing the second and third questions. Indicator systems may be defined as limited sets of issue-related parameters (quantitative/qualitative statements or measured/observed parameters) that can be used to describe existing situations (the dynamic state of a coastal system) and measure changes or trends over time (UNESCO, 2006). Three distinct types of indicator system were identified in our sample: indicators of sustainability, indicators of vulnerability, and pressure-state indicators. Indicators of sustainability are composite indices that describe the status of the environmental, economic, and social subsystems in the coastal zone (e.g. Smith et al., 2007). Indicators of vulnerability seek to determine the risk of specific adverse outcomes with regard to a variety of stresses for a particular group or unit of concern (Clark et al., 2000), such as coastal communities or coral reef ecosystems (e.g. Yoo et al., 2011). Finally, pressure-state indicators reveal existing linkages between anthropogenic activity and environmental degradation (e.g. Mangi et al., 2007). 


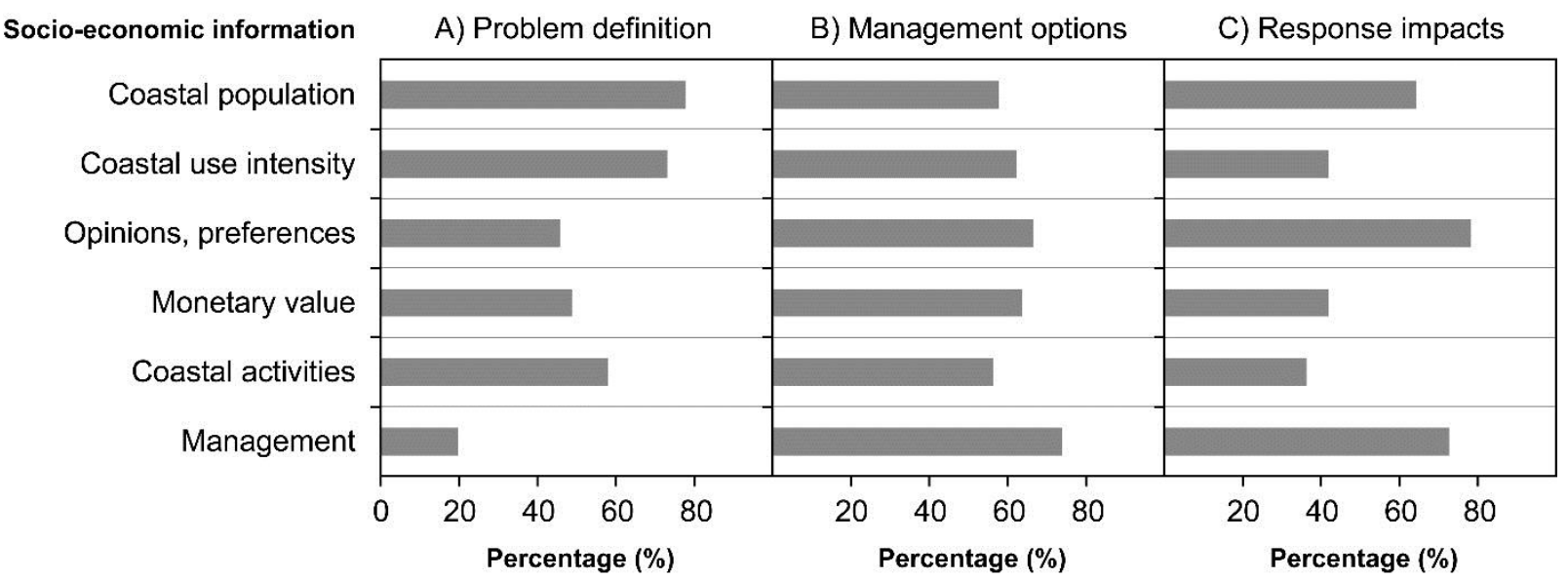

Fig. 7. Frequency of occurrence of the principal types of socio-economic information classified by the goals of socio-economic assessments, expressed as a percentage of (A) all papers dealing with "problem definition" ( $n=66$ ), (B) all papers dealing with "management options" ( $n=68)$, and (C) all papers dealing with "response impacts" $(n=36)$. (See also Supplement 3 ).

\subsubsection{Management options (ex ante)}

The "management options" step is more diverse from the point of view of socio-economic information and tool/methodology needs than "problem definition" and "response impacts" (Fig. 7). Surveys and monetary valuations are always useful, but it is "scenario, prospective" which is the first tool/methodology employed in this situation. This category encompasses two distinct tools/methodologies which are often used together: scenario building and prospective simulation. "Scenarios portray images of how society and its supporting environment could look, given different sets of assumptions and consequent conditions" (Ledoux et al., 2005, p. 87) (e.g. Tompkins et al., 2008). Prospective simulation is often based on the exploratory modeling of changes induced by the various defined scenarios (e.g. Mongruel et al., 2011). CBA and CEA are also used in the management options step for performing comparative analyses of alternative courses of action in terms of both their costs and consequences (e.g. Turner et al., 2007). Multi-criteria analysis (MCA) is less often employed than CBA or CEA, and differs from them in that the choice between a set of alternative options is made on the basis of a set of defined evaluation criteria (Fig. 8). MCA is often used to support coastal management decisions where there are conflicting management objectives and conflicting stakeholder preferences (e.g. Roca et al., 2008). Participatory approaches are essentially used to define scenarios or weighting criteria for MCA in collaboration with local stakeholders in order to incorporate their preferences and values for supporting the decision-making process (e.g. Roca et al., 2008).

\subsubsection{Response impacts (ex post)}

Policy impact (or "response impact") assessment requires very different socio-economic information and tools/methodologies from the "problem definition" step (Fig. 7, Fig. 8). The most widely used methodology is still the survey, but in this case for measuring socio-economic impacts and/or perception of the outcomes of the management initiatives implemented (e.g. Webb et al., 2004). Opinion data are much more widely used than monetary value for measuring the management of outcomes, no doubt because situations in which economic data are scarce require the use of data about perceptions, as Carneiro (2011) notes. Similarly, trend analysis is only employed when enough historical data are available; indicator systems are less often used for response impact assessment, no doubt because they have only recently come into use and also because such systems are difficult to maintain over time. Management data are the second most frequently employed type, and consist essentially in 
management cost descriptions (e.g. Munoz-Perez et al., 2001). They are sometimes conjoined with the benefits provided by CZM programs implemented by means of CBA in order to determine whether benefits outweigh costs (e.g. Peng et al. 2006).

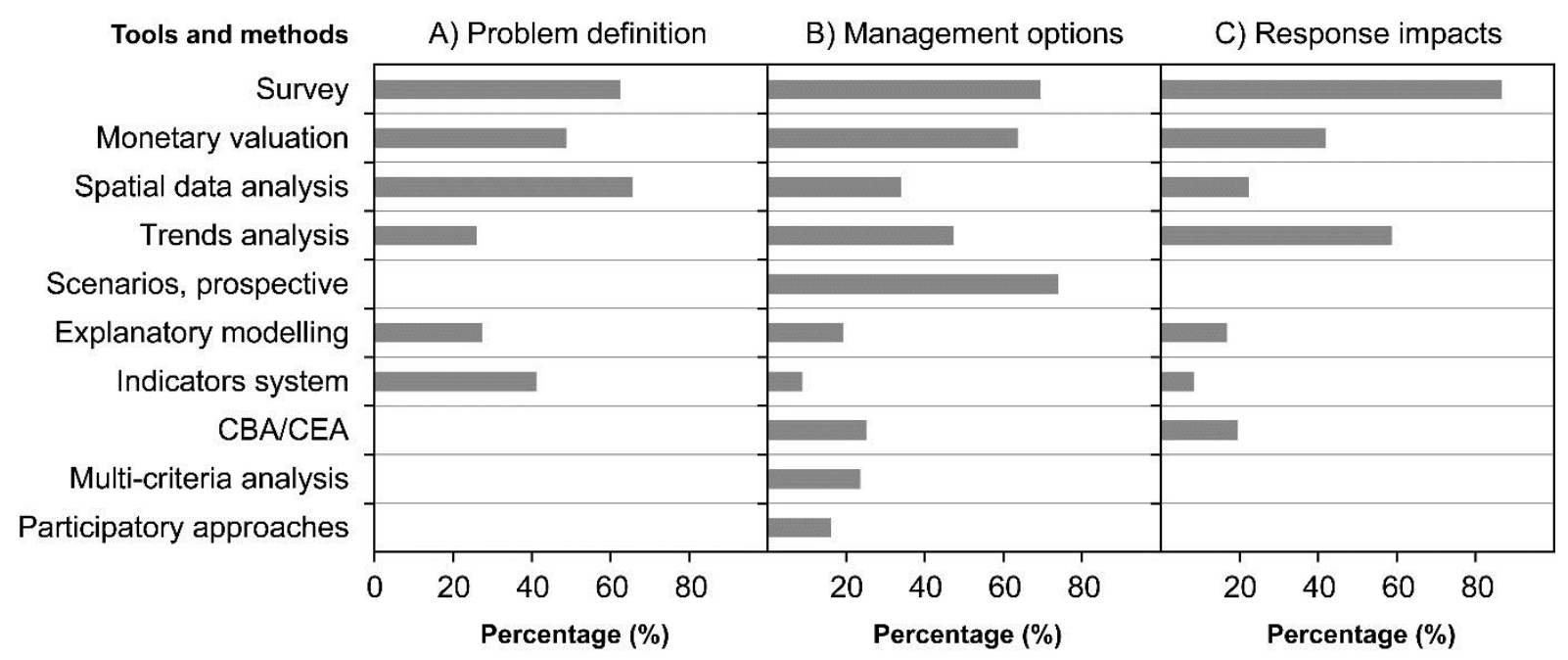

Fig. 8. Frequency of occurrence of tools and methods in terms of the goals of socio-economic assessments, expressed as a percentage of (A) all papers dealing with "problem definition" $(n=66),(B)$ all papers dealing with "management options" $(n=68)$, and $(C)$ all papers dealing with "response impacts" ( $n=36)$. (See also Supplement 3)

\section{Discussion}

In investigating the implementation of socio-economic assessments in support of CZM, it may be asked how this kind of assessment is used by a community of researchers and managers from varying scientific backgrounds. According to Ostrom (2009), "understanding of the processes that lead to improvements in or deterioration of natural resources is limited, because scientific disciplines use different concepts and languages to describe and explain complex social-ecological systems. Without a common framework to organize findings, isolated knowledge does not cumulate" (p. 419). In line with this kind of thinking, the need to undertake integrated assessments for best science-management integration has been emphasized in the literature dealing with environmental management (Turner, 2000; Nobre, 2009). This framework helps to make complex issues understandable for decision-makers and stakeholders on the basis of procedural and iterative approaches. However, it remains true that the operational implementation of an "integration" process is always a challenging task in the field of CZM even if real progress has been made since the period of "coastal area management" as it was implemented in the 1960s (Vallega 1999).

Most of the studies reviewed in this paper bring together several of the specific forms of integration for producing knowledge in support of ICZM as identified by van Kouwen et al. (2008). Interdisciplinary approaches are often employed to take into account both socio-economic and biophysical aspects of coastal systems and their interrelationships. Many of the papers examined include spatiotemporal dimensions for the understanding of the spatial and temporal dynamics of coastal activities, the coastal environment, and the effects (or potential effects) of management decisions. Human behaviors are captured from very diverse perspectives, and forecasting and backcasting, even if not yet widespread, are rapidly expanding both in the case of management option analysis (policy design) and response impact assessments (policy evaluation). While all these approaches contribute to a more holistic view and a better understanding of social-ecological system complexities, uncertainty due to lack of 
knowledge relevant to policy purposes is least often explicitly addressed in our reference materials, no doubt because it is "unquantified uncertainty" (van Kouwen et al., 2008, p. 22). Being sparse and open to conflicting interpretations, socio-economic information accounts for a significant part of the uncertainty and lack of consensus about knowledge of coastal zones.

Because lack of knowledge cannot justify inaction, the challenge for coastal societies is to make decisions in this situation of uncertainty, that is, of "incomplete and controversial" knowledge (Billé, 2008, p. 83). According to Raymond et al. (2010), one way to manage the scope, complexity, and uncertainty of environmental problems is to make use of different types and sources of knowledge: scientific and practical, expert and non-expert. Hisschemöller and Hoppe (1996) highlight the need to structure problems through the participation of stakeholders with different views on the problem in question, in order to get greater consensus about which relevant information, norms, and values are at stake in the process of problem-solving. In this context, participatory process in its various forms - contractual, consultative, collaborative, or collegial (Barreteau et al., 2010) - can be seen as an effective contribution to "sustainable coastal management strategy" (Treby and Clark, 2004, p. 362). It is widely suggested that participation can increase the chances of efficient environmental management (Brown et al., 2001; Treby and Clark, 2004) because this process has "the potential to enable realistic and holistic sustainable management through behavior change" (Treby and Clark, 2004, p. 356).

In the course of this review of the literature, we have identified several types of participatory process, implemented for distinct purposes. They do not necessarily correspond to the highest level of participation (collegiate) because that is not the appropriate process in every situation. Depending on the issues and coastal zone in question, many different levels and types of participatory process may be needed to satisfy all the stakeholders involved (Treby and Clark, 2004), the only essential question being "about how participation will be implemented, and what kind of involvement is expected from participants" (Barreteau et al., 2010). Fernandes et al. (1999) took a participatory approach to defining the management problems of a coral reef in a small island state. Several authors have proposed participatory methods for the design of indicator systems as a tool to measure the effectiveness of CZM programs (Fontalvo-Herazo et al., 2007; Vella et al., 2009; Pajaro et al., 2010). Others employ the participatory process for defining alternative management strategies (Tompkins et al., 2008; Soma, 2010) and in some cases test the scenarios defined with stakeholders by applying multi-criteria analysis or soft social-ecological modeling approaches, then share and discuss results with all the participants (Roca et al., 2008, Garmendia et al., 2010, Franzén et al., 2011; Mongruel et al., 2011; Tomlinson et al., 2011). All these approaches display the benefits of integrating different views to support unstructured problem-solving. They can be used for problem definition, analysis of options, identification of goals and strategies, impact assessment, and communication of results (Hisschemöller et al., 2001). Incorporating diverse types of expertise and value enhances the social-ecological robustness of the political process as well as its evaluation using appropriate and shared/recognized criteria. It usefully complements quantitative assessment with mathematical models because it ensures that the problem is well defined and not disconnected from the decision-maker's question (Hisschemöller et al., 2001). The major drawbacks of participatory activity seem to be that it is time-consuming and that it can generate fortuitous results due to external factors or the design and execution of the project itself (Hisschemöller et al., 2001). The proper identification and selection of stakeholders is crucial.

In addition to providing data and information that complement those from the natural sciences, the social sciences can contribute to stimulating science-management integration by strengthening the incorporation of controversial preferences, values, and knowledge in the policy advice process, in a context of uncertainty and complexity (unstructured problems). Participatory approaches are not intended to reduce uncertainty but to describe it more accurately by giving more attention to the heterogeneity of views of the policy as well as the science communities. They help stakeholders and scientists to view development and conservation choices as political facts, and to understand that some current controversial issues are irreducible and that sustainable development consists in tradeoffs for 
achieving acceptable and effective solutions. However, bridging the gap between claims about the use of integrated and participatory approaches and their actual implementation has to be done by the scientific community as a whole, both social and natural scientists. Most scientists interested in CZM still need to educate and train themselves in the existing analytical frameworks and methodologies for integrated and participatory approaches in order to avoid disappointing stakeholders, managers, and any other participants in these initiatives.

\section{Conclusion}

A systematic review of the research literature for the period 1992-2011 concerned with socio-economic assessments in support of CZM was conducted. Socio-economic assessments, which are increasingly recommended (Cooper and McLaughlin, 1998; Turner, 2000; Bowen and Riley, 2003; Ban et al., 2009; Nobre, 2011), seem also to be increasingly implemented: this research topic saw a major and continuing increase in both absolute and relative numbers of published papers in WoS. However, it is included in only a small proportion (10.1\%) of CZM articles overall. Our systematic review aims to provide a synthesis of the uses of socio-economic assessments in support of CZM with reference to several aspects: the political and scientific context, the issue at stake, the interactions within coastal systems, the aim of the assessment from a management perspective, the conceptual or analytical framework, and the methods and tools of assessment.

Over half of these socio-economic assessments have been carried out using interdisciplinary approaches, and this research field is mostly driven by research conducted in northwestern Europe. The papers selected mainly focus on topics related to "environmental degradation" and "coastal economy, livelihood," and the most frequently studied interaction is the social impact of changes in the environmental situation of the coastal system. However, there are major disparities in research effort and concerns depending on the level of economic development of the country in which the case studies were conducted. Case studies in high-income countries are more numerous than in low- and middleincome economies, and above all there is a disparity in the type of coastal issues addressed. As one might expect, the amenities and welfare of the coastal population are more often studied in "leisure societies" (high-income countries), but it is more disquieting that coastal hazards are less well documented in low- and middle-income economies where coastal populations are especially vulnerable to extreme events. This result indicates a first mismatch between social needs and socio-economic research on CZM.

Even though our results do not demonstrate the direct influence of international environmental policy events on socio-economic research in the field of CZM, they do show that the most commonly invoked conceptual and analytical frameworks have become more popular in part due to important international conventions and scientific working groups. Indeed, since the Rio Conference in 1992, "sustainability," "integration," "perception," and "valuation" have been the most frequently cited conceptual frameworks in the literature. During the most recent period (2007-2011), "preference/choice," "participation," and "ecosystem services" have clearly emerged as promising approaches. "Risk and vulnerability," "DPSIR," "valuation," "ecosystem services," and "preference/ choice" appear to be the conceptual frameworks that lead to effective socio-economic assessments. In contrast, although they are the most often invoked, "integration," "sustainability," and "participation" are frameworks that rarely lead to the effective implementation of the corresponding methods and tools (namely "integrated approaches," sustainability assessments," and "participatory approaches"), because it is difficult to operationalize them. This result reflects a second mismatch between social needs and CZM research.

Our review also shows how the use of socio-economic assessments varies depending on the management objectives being pursued. The socio-economic assessments are frequently used in the 
first two steps of the CZM process, "problem definition" and "management options" (40\% of the papers for each of these purposes), and more rarely for the ex post evaluation of management (less than $20 \%$ of the papers deal with "response impacts"). This result confirms that measurements of the CZM program's effectiveness are rare (Knecht et al., 1996; Olsen et al., 1997; McFadden, 2007) because of the overall lack of outcome-related information and data (Knecht et al. 1996, Carneiro, 2011) and "the difficulty involved in selecting criteria to measure the system's performance" (Nobre, 2011, p. 282).

This systematic literature review demonstrates that the most common current types of socio-economic information describe coastal populations (demographic and livelihood characteristics), their opinions (main concerns, quality of the environment), and intensity of coastal use, while the most frequently employed methodologies are "survey," "monetary valuation," and "spatial data analysis." Scenarios and prospective exercises appear to be the typical methodologies for comparing management options, while trend analysis is the second most preferred method for response impact assessment. The social sciences thus seem able to contribute in a structured way to the definition of CZM policy and the assessment of CZM programs with the help of specific methodologies and analytical frameworks based on explicit and advanced statistical analysis (explanatory modeling and prospective simulation).

More interesting, our review shows that there is some potential for improving the usefulness of socioeconomic assessment in support of CZM. Indicator systems, as well as spatial data analyses, are frequently built for the initial step of problem definition, but tend to disappear during the subsequent management steps: this suggests that further efforts are needed to design both indicator systems and spatial information in such a way that they would operate right up to the ex post policy evaluation step. Multi-criteria analyses, which are only used for comparing management options, could also be implemented during the response impact evaluation step, since they provide a powerful framework for assessing the typically multi-objective aspects of CZM policies. Lastly, the institutional analysis of the management system and the analysis of the public's opinions and preferences could be more systematically used from the beginning of the CZM process, that is, during the problem definition step. This would enable management analysis to address the feasibility of institutional change as much as its efficiency and would allow opinion analysis to contribute to understanding the public's own expectations as much as its willingness to accept management decisions and the results of those decisions.

\section{Acknowledgments}

The research leading to these results has received funding from the [European Union] Seventh Framework Programme ([FP7/2007- 2013] [FP7/2007-2011]) under grant agreement $n^{\circ}$ [244170].

\section{References}

Ban, N. C., Hansen, G. J. A., Jones, M., Vincent, A. C. J., 2009. Systematic marine conservation planning in data-poor regions: Socioeconomic data is essential. Marine Policy 33, 794-800.

Barreteau, O., Bots, P. W. G., Daniell, K. A., 2010. A framework for clarifying "participation" in participatory research to prevent its rejection for the wrong reasons. Ecology and Society 15 (2): 1. [online] URL: http://www.ecologyandsociety.org/vol15/iss2/art1/

Billé, R., 2008. Integrated Coastal Zone Management: four entrenched illusions. S.A.P.I.E.N.S 1 (2), 7586. [Online]. URL: http://sapiens.revues.org/198

Booth, A., Papaioannou, D., Sutton, A., 2012. Systematic approaches to a successful literature review. SAGE Publications, Los Angeles, London, New Delhi, Singapore, Washington D.C., 279 pp.

Bowen, R. E., Riley C., 2003. Socio-economic indicators and integrated coastal management. Ocean \& Coastal Management 46, 299-312. 
Brenner, J., Jimenez, J. A., Sarda, R., Garola, A., 2010. An assessment of the non-market value of the ecosystem services provided by the Catalan coastal zone, Spain. Ocean \& Coastal Management 53, 27-38.

Bruntland, G. H., 1987. Our Common Future. Report of the World Commission on Environment and Development. United Nations, Oslo, 247 pp.

Carneiro, G., 2011. Marine management for human development: A review of two decades of scholarly evidence. Marine Policy 35, 351-362.

Chang, Y.C., Hong, F.W., Lee, M.T., 2008. A system dynamic based DSS for sustainable coral reef management in Kenting coastal zone, Taiwan. Ecological Modelling 211, 153-168.

Cicin-Sain, B., 1993. Sustainable development and integrated coastal management. Ocean \& Coastal Management 21 (1), 11-43.

Cicin-Sain, B., Knecht, R. W., 1998. Integrated coastal and ocean management: Concepts and practices. Island Press, Washington D.C., 517 pp.

Clark, J. R., 1997. Coastal zone management handbook. CRC Press, Florida, 720 pp.

Clark, W. C., Jaeger, J., Corell, R., Kasperson, R., McCarthy, J. J., Cash, D., Cohen, S. J., Desanker, P., Dickson, N. M., Epstein, P., Guston, D. H., Hall, J. M., Jaeger, C., Janetos, A., Leary, N., Levy, M. A., Luers, A., MacCracken, M., Melillo, J., Moss, R., Nigg, J. M., Parry, M. L., Parson, E. A., Ribot, J. C., Schellnhuber, H. J., Schrag, D. P., Seielstad, G. A., Shea, E., Vogel, C., Wilbanks, T. J., 2000. Assessing vulnerability to global environmental risks. Report of the Workshop on Vulnerability to Global Environmental Change: Challenges for Research, Assessment and Decision Making. 22-25 May, Airlie House, Warrenton, Virginia, USA, 7 pp.

Cooper, H.M., 1988. Organizing knowledge synthesis: A taxonomy of literature reviews. Knowledge in Society 1, 104-126.

Cooper, H.M., Hedges, L.V., 2009. Research synthesis as a scientific process. In: Cooper, H., Hedges, L.V., Valentine, J.C. (Eds.), The handbook of research synthesis and meta-analysis. Russell Sage Foundation, New York, 600 pp.

Cooper, J. A. G., McLaughlin, S., 1998. Contemporary multidisciplinary approaches to coastal classification and environmental risk analysis. Journal of Coastal Research 14 (2), 512-524.

Cordier, M., Pérez Agúndez, J. A., O'Connor, M., Rochette, S., Hecq, W., 2011. Quantification of interdependencies between economic systems and ecosystem services: An input-output model applied to the Seine estuary. Ecological Economics (70) 9, 1660-1671.

Cullen-Unsworth, L. C., Pretty, J., Smith, D. J., 2011. Developing community-derived indicators of economic status in the coral triangle: A management support tool. Ocean \& Coastal Management 54, 446-454.

Dumazedier, J., 1962. Vers une civilisation du loisir ? Editions du Seuil, Paris, 320 pp.

Falagas, M. E., Pitsouni, E. I., Malietzis, G. A., Pappas, G., 2008. Comparison of PubMed, Scopus, Web of Science, and Google Scholar: Strengths and weaknesses. The FASEB Journal 22, 338-342.

Fernandes, L., Ridgley, M. A., van't Hof, T., 1999. Multiple criteria analysis integrates economic, ecological and social objectives for coral reef managers. Coral Reefs 18, 393-402.

Fletcher, S., 2003. Stakeholder representation and the democratic basis of coastal partnerships in the UK. Marine Policy 27, 229-240. 
Fontalvo-Herazo, M. L., Glaser, M., Lobato-Ribeiro, A., 2007. A method for the participatory design of an indicator system as a tool for local coastal management. Ocean \& Coastal Management 50, 779795.

Forst, M. F., 2009. The convergence of Integrated Coastal Zone Management and the ecosystems approach. Ocean \& Coastal Management 52, 294-306.

Franzén, F., Kinell, G., Walve, J., Elmgren, R., Söderqvist, T., 2011. Participatory social-ecological modeling in eutrophication management: The case of Himmerfjärden, Sweden. Ecology and Society 16 (4): 27. [online] URL: http://dx.doi.org/10.5751/ES-04394-160427

Franzosi, R., 2008. Content analysis. SAGE Publications, Los Angeles, London, New Delhi, Singapore, Washington D.C., 4 vols., 1696 pp.

Garmendia, E., Gamboa, G., Franco, J., Garmendia, J. M., Liria, P., Olazabal, M., 2010. Social multicriteria evaluation as a decision support tool for integrated coastal zone management. Ocean \& Coastal Management 53, 385-403.

Gormsen, E., 1997. The impact of tourism on coastal areas. GeoJournal 42 (1), 39-54.

Harremoës, P., Turner, R., 2001. Methods for Integrated Assessment. Regional Environmental Change 2 (2), 57-65.

Hisschemöller, M., Hoppe, R., 1996. Coping with intractable controversies: The case for problem structuring in policy design and analysis. Knowledge and Policy 8 (4), 40-60.

Hisschemöller, M., Tol, R. S. J., Vellinga, P., 2001. The relevance of participatory approaches in integrated environmental assessment. Integrated Assessment 2, 57-72.

Hunt, M., 1997. How science takes stock: The story of meta-analysis. Russell Sage Foundation, New York, $210 \mathrm{pp}$.

Kildowa, J. T., Mcllgorm, A., 2010. The importance of estimating the contribution of the oceans to national economies. Marine Policy 34, 367-374.

King, D. A., 2004. The scientific impact of nations. Nature 430, 311-316.

Knecht, R. W., Cicin-Sain, B., Fisk, G. W., 1996. Perceptions of the performance of state coastal zone management programs in the United States. Coastal Management 24, 141-163.

Laurans, Y., Rankovic, A., Billé, R., Pirard, R., Mermet, L., 2013. Use of ecosystem services economic valuation for decision making: Questioning a literature blindspot. Journal of Environmental Management 119, 208-219.

Ledoux, L., Beaumont, N., Cave, R., Turner, R. K., 2005. Scenarios for integrated river catchment and coastal zone management. Regional Environmental Change 5, 82-96.

Lloret, J., Zaragoza, N., Caballero, D., Riera, V., 2008. Impacts of recreational boating on the marine environment of Cap de Creus (Mediterranean Sea). Ocean \& Coastal Management 51, 749-754.

Mangi, S. C., Roberts, M. C., Rodwell, L. D., 2007. Reef fisheries management in Kenya: Preliminary approach using the driver-pressure-state-impacts-response (DPSIR) scheme of indicators. Ocean \& Coastal Management 50, 463-480.

McFadden, L., 2007. Governing coastal spaces: The case of disappearing science in integrated coastal zone management. Coastal Management 35, 429-443.

Mongruel, R., Prou, J., Ballé-Béganton, J., Lample, M., Vanhoutte-Brunier, A., Réthoret, H., Pérez Agúndez, J., Vernier, F., Bordenave, P., Bacher, C., 2011. Modeling soft institutional change and the improvement of freshwater governance in the coastal zone. Ecology and Society 16 (4): 15. [online] URL: http://dx.doi.org/10.5751/ES-04294-160415 
Morgan, R., 1999. Preferences and priorities of recreational beach users in Wales, UK. Journal of Coastal Research 15 (3), 653-667.

Munoz-Perez, J. J., de San Roman-Blanco, B. L., Gutierrez-Mas, J. M., Moreno, L., Cuena, G. J., 2001. Cost of beach maintenance in the Gulf of Cadiz (SW Spain). Coastal Engineering 42, 143-153.

Nobre, A. M., 2009. An ecological and economic assessment methodology for coastal ecosystem management. Environmental Management 44, 185-204.

Nobre, A. M., 2011. Scientific approaches to address challenges in coastal management. Marine Ecology Progress Series 434, 279-289.

Nogueira de Andrade, M. M., Szlafsztein, C. F., Souza-Filho, P. W. M., dos Reis Araújo, A., Tavares Gomes, M. K., 2010. A socioeconomic and natural vulnerability index for oil spills in an Amazonian harbor: A case study using GIS and remote sensing. Journal of Environmental Management 91, 19721980.

Olsen, S. B., 1993. Will Integrated Coastal Management Programs be sustainable: The constituency problem. Ocean \& Coastal Management 21, 201-225.

Olsen, S. B., 2002. Assessing progress toward the goals of coastal management. Coastal Management 30 (4), 325-345.

Olsen, S., Tobey, J., Kerr, M.,1997. A common framework for learning from ICM experience. Ocean \& Coastal Management 37, 155-174.

Ostrom, E., 2009. A general framework for analyzing sustainability of social-ecological systems. Science $325,419-422$.

Pajaro, M., G., Mulrennan, M., E., Alder, J., Vincent, A. C. J., 2010. Developing MPA effectiveness indicators: Comparison within and across stakeholder groups and communities. Coastal Management 38 (2), 122-143.

Peng, B., Hong, H., Xue, X., Jin, D., 2006. On the measurement of socioeconomic benefits of integrated coastal management (ICM): Application to Xiamen, China. Ocean \& Coastal Management 49, 93-109.

Pontecorvo, G., Wilkinson, M., Anderson, R., Holdowsky, M., 1980. Contribution of the ocean sector to the United States economy. Science 208 (4447), 1000-1006.

Portman, M. E., Jin, D., Thunberg, E., 2011. The connection between fisheries resources and spatial land use change: The case of two New England fish ports. Land Use Policy 28, 523-533.

Raymond, C. M., Fazey, I., Reed M. S., Stringer, L. C., Robinson, G. M., Evely, A. C., 2010. Integrating local and scientific knowledge for environmental management. Journal of Environmental Management 91, 1766-1777.

Rice, W.R., 1989. Analyzing tables of statistical tests. Evolution 43 (1), 223-225.

Roca, E., Gamboa, G., Tàbara, D. J., 2008. Assessing the multidimensionality of coastal erosion risks: Public participation and multicriteria analysis in a Mediterranean coastal system. Risk Analysis 28 (2), 399-412.

Rotmans, J., Dowlatabadi, H., 1997. Integrated Assessment modeling. Human Choice and Climate Change 3, 291-377.

Samonte-Tan, G. P. B., White, A. T., Tercero, M. A., Diviva, J., Tabara, E., Caballes, C., 2007. Economic valuation of coastal and marine resources: Bohol Marine Triangle, Philippines. Coastal Management 35 (2), 319-338. 
Sarda, R., Avila, C., Mora, J., 2005. A methodological approach to be used in integrated coastal zone management processes: The case of the Catalan Coast (Catalonia, Spain). Estuarine, Coastal and Shelf Science 62, 427-439.

Sharma, K. K., 2004. World tourism today. Sarup \& Sons Publishers, New Delhi, 271 pp.

Shmueli, G., 2010. To explain or to predict? Statistical Science 25 (3), 289-310.

Smith, M. K. S., King, C. M., Sauer, W. H. H., Cowley, P. D., 2007. Development of fishery indicators for local management initiatives - a case study for Plettenberg Bay, South Africa. African Journal of Marine Science 29 (3), 511-525.

Soma, K., 2010. Framing participation with multicriterion evaluations to support the management of complex environmental issues. Environmental Policy and Governance 20, 89-106.

Tomlinson, B., Sastre, S., Blasco, D., Guillén, J., 2011. The systems approach framework as a complementary methodology of adaptive management: A case study in the urban beaches of Barcelona. Ecology and Society 16 (4): 28. [online] URL: http://dx.doi.org/10.5751/ES-04484-160428

Tompkins, E. L., Few, R., Brown, K., 2008. Scenario-based stakeholder engagement: Incorporating stakeholders preferences into coastal planning for climate change. Journal of Environmental Management 88, 1580-1592.

Treby, E. J., Clark, M. J., 2004. Refining a practical approach to participatory decision making: An example from coastal zone management. Coastal Management 32 (4), 353-372.

Turner, R. K., Burgess, D., Hadley, D., Coombes, E., Jackson, N., 2007. A cost-benefit appraisal of coastal managed realignment policy. Global Environmental Change 17, 397-407.

UNESCO, 2006. A handbook for measuring the progress and outcomes of integrated coastal and ocean management. IOC, UNESCO Publishing, Paris, 224 pp.

UNESCO, 2010. World social science Report: Knowledge divides. UNESCO Publishing, Paris, 443 pp.

Vallega, A., 1999. Fundamentals of Integrated Coastal Management. Kluwer Academic Publishers, Dordrecht, Boston, London, $264 \mathrm{pp}$.

van der Sluijs, J. P., 2002. Integrated Assessment. Encyclopedia of Global Environmental Change 4, 250-253.

van Kouwen, F., Dieperink, C., Schot, P., Wassen, M., 2008. Applicability of decision support systems for Integrated Coastal Zone Management. Coastal Management, 36 (1), 19-34.

Vella, P., Bowen, R. E., Frankic, A., 2009. An evolving protocol to identify key stakeholder-influenced indicators of coastal change: The case of Marine Protected Areas. ICES Journal of Marine Science 66, 203-213.

Ward, P., Shively, G., 2012. Vulnerability, income growth and climate change. World Development 40 (5), 916-927.

Webb, E. L., Maliao, R. J., Siar, S. V., 2004. Using local user perceptions to evaluate outcomes of protected area management in the Sagay Marine Reserve, Philippines. Environmental Conservation 31 (2), 138-148.

World Bank, 2013. GNI per capita, Atlas method (current US\$). http://data.worldbank.org/.

Yoo, G., Hwan Hwang, J., Choi, C., 2011. Development and application of a methodology for vulnerability assessment of climate change in coastal cities. Ocean \& Coastal Management 54, 524-534 
Supplement 1. Literature used in quantitative analysis (list of peer-reviewed papers, $n=170$ ) 
\begin{tabular}{|l|}
\hline Authors \\
\hline Delgado-Gonzalez, O. E.; Jimenez, J. A.: Espejel, I. Ferman- \\
\hline A
\end{tabular} Delgado-Gonzalez, O. E.; Jimenez, J. A.; Espejel, l.; Ferm
Almada, J. L.; Martinez-Diaz-de-Leon, A.; Mejia-Trejo, A.; Seingier, G.

Koutrakis, E.; Sapounidis, A.; Marzetti, S.; Marin, V.; Roussel, S.; Martino, S.; Fabiano, M.; Paoli, C.; Rey-Valette, H.; Povh, D.; Malvarez, C.

作,

Hecq, W.
Luisetti, T.; Turner, R. K.; Bateman, I. J.; Morse-Jones, S.;

Adams, C.; Fonseca, L.

Vanhooren, S.; Maelfait, H.; Belpaeme, K.

Nobre, A. M.: Bricker, S. B.; Ferreira, J. G. Yan, X. De Wit,

M.; Nunes, J. P.
Franzen, F.; Kinell, G.; Walve, J.; Elmgren, R.; Soderqvist, T.

Moksness, E.; Gjosaeter, J.; Lagaillarde, G.; Mikkelsen, E.

Olsen, E. M.; Sandersen, H. T.; Volstad, J. H.

Vanhoutte-Brunier, A.; Rethoret, H.; Agundez, J. A. P.; Vernie

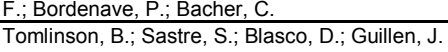

Duvat, V.

Yang, C.-M.; Li, J.-J.; Chiang, H.-C.

Pablo Lozoya, J.; Sarda, R.; Jimenez, J. A. Peterson, A. M.; Stead, S.M. M.

Yoo, G.; Hwang, J. H.; Choi, C.

Zacarias, D. A.; Williams, A. T.; Newton, A.

Omo-Irabor, O. O.; Olobaniyi, S. B.; Akunna, J.; Venus, V.; Mortman, M. E.; Jin, D.; Thunberg, E.

Cullen-Unsworth, Leanne C.; Pretty, Jules; Smith, David J. Diedrich, A.; Balaguer Huguet, P.; Tintore Subirana, J.

Seingier, G.; Espejel, I.; Luis Ferman-Almada, J.; Delgado

Aramburo-Vizcarra, G. Moctezuma, G.; Azuz-Adeath, I.; Aramburo-Vizcarra, $G$

Batista, M. I.; Baeta, F.; Costa, M. J.; Cabral, H. N.

de Souza Filho, J. R.; Silva, I. R.; Ferreira, D. F. \begin{tabular}{l}
\hline House, C.; Williams, J.; Cullis, M. J.; Phillips, M. R. \\
\hline Gomes, R. K. S.; Takiyama, L. R.; Pereira, L. C. C.; Silva, U.
\end{tabular}

R. L.; Ferreira, R. C. M.

Sayan, S.; Williams, A. T.; Johnson, D. E.; Uenal, O.
Title

Aquaculture potential of Mexican coasts

area

Investigating the preferences of individuals in redeveloping waterfronts: The case of the port of Thessaloniki - Greece

endencies between economic systems and ecosystem services: An

input-output model applied to the Seine estuary
Coastal and marine ecosystem services valuation for policy and management: Managed

realignment case studies in England

Moving towards an ecological management of the beaches

th of coastal ecosystems: Application for

Participatory social-ecological modeling in eutrophication management: The case of

Effects of fishing tourism in a coastal municipality: A case study from Risor, Norway zone

The systems approach framework as a complementary methodology of adaptive management: A case study in the urban beaches of Barcelon

作

Stakeholders' perspective on the sustainable utilization of Marine Protected Areas in Green

\begin{tabular}{l} 
Island, Taiwan \\
A methodological framework for multi-hazard risk assessment in beaches \\
\hline R
\end{tabular}

A coaking and livelihood options in Marine Protected Areas

Development and application of a methodology for vulnerability assessment of climate change in coastal cities

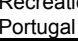

Mangrove vulnerability modelling in parts of Western Niger Delta, Nigeria using satellite images,

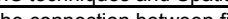

land use change: The case of two New

support tool

Dre

Mexico's coasts: Half-way to sustainability

MPA as management tools for small-scale fisheries: The case study of Arrabida Marine Protected Area (Portugal)

Socio-environ

Coastal sustainability: A comparative socio-economic lifestyle assessment. South Wales. UK Social diagnosis and guidelines for coastal management in environmental protection areas of the Amazon littoral (Amapa, Brazil)

The sustainable carrying capacity as a tool for environmental beach management
A pilot study for sustainable tourism in the coastal zone of Antalya, Turkey: Tourists, turtles or
both?

\begin{tabular}{|c|c|c|c|c|c|}
\hline Journal & Volume & Issue & & & Year \\
\hline \begin{tabular}{|l} 
JOURNAL OF COASTAL RESEARCH \\
\end{tabular} & 27 & 6 & 1137 & 1147 & 2011 \\
\hline OCEAN \& COASTAL MANAGEMENT & 54 & 11 & 821 & 830 & 2011 \\
\hline CITIES & 28 & 5 & 424 & 432 & 2011 \\
\hline ECOLOGICAL ECONOMICS & 70 & 9 & 1660 & 1671 & 2011 \\
\hline OCEAN \& COASTAL MANAGEMENT & 54 & 3 & 212 & 224 & 2011 \\
\hline \begin{tabular}{|l} 
JOURNAL OF COASTAL RESEARCH \\
\end{tabular} & & & 81 & 86 & 2011 \\
\hline JOURNAL OF COASTAL RESEARCH & & & $\frac{1415}{536}$ & $\frac{1419}{555}$ & 2011 \\
\hline COASTAL MANAGEMENT & 39 & 5 & 536 & 555 & \\
\hline ECOLOGY AND SOCIETY & 16 & 4 & - & - & 2011 \\
\hline ECOLOGY AND SOCIETY & 16 & 3 & - & - & 2011 \\
\hline ECOLOGY AND SOCIETY & 16 & 4 & - & - & 2011 \\
\hline ECOLOGY AND SOCIETY & 16 & 4 & - & - & 2011 \\
\hline OCEAN \& COASTAL MANAGEMENT & 54 & 11 & 831 & 843 & 2011 \\
\hline OCEAN \& COASTAL MANAGEMENT & 54 & 10 & 771 & 780 & 2011 \\
\hline \begin{tabular}{|l|l|} 
ENVIRONMENTAL SCIENCE \& POLICY \\
\end{tabular} & 14 & 6 & 685 & 696 & 2011 \\
\hline \begin{tabular}{|l} 
ENVIRONMENTAL \\
\end{tabular} & 38 & 3 & \begin{tabular}{|l|l|}
342 \\
\end{tabular} & 352 & 2011 \\
\hline $\begin{array}{l}\text { JOURNAL OF COASTAL } \\
\text { CONSERVATION }\end{array}$ & 15 & 3 & 393 & 405 & 2011 \\
\hline OCEAN \& COASTAL MANAGEMENT & 54 & 7 & 524 & 534 & 2011 \\
\hline APPLIED GEOGRAPHY & 31 & 3 & 1075 & 1081 & 2011 \\
\hline $\begin{array}{l}\text { ENVIRONMENTAL MONITORING AND } \\
\text { ASSESSMENT }\end{array}$ & 178 & - & 39 & 51 & 2011 \\
\hline LAND USE POLICY & 28 & 3 & 523 & 533 & 2011 \\
\hline OCEAN \& COASTAL MANAGEMENT & 54 & 6 & 446 & 454 & 2011 \\
\hline OCEAN \& COASTAL MANAGEMENT & 54 & 4 & 341 & 351 & 2011 \\
\hline ECOLOGICAL INDICATORS & 11 & 2 & 633 & 642 & 2011 \\
\hline OCEAN \& COASTAL MANAGEMENT & 54 & 2 & 123 & 128 & 2011 \\
\hline OCEAN \& COASTAL MANAGEMENT & 54 & 2 & 137 & 147 & 2011 \\
\hline JOURNAL OF COASTAL RESEARCH & - & - & 446 & 451 & 2011 \\
\hline JOL & & & 1233 & 1237 & 2011 \\
\hline JOURNAL OF COASTAL RESEARCH & - & - & 1331 & 1335 & 2011 \\
\hline & & & 1411 & 1414 & 2011 \\
\hline \begin{tabular}{|l|} 
JOURNAL OF COASTAL RESEARCH \\
\end{tabular} & & & 1806 & 1810 & 2011 \\
\hline
\end{tabular}




\begin{tabular}{|c|c|}
\hline Ruiz-Frau, A.; Edwards-Jones, G.; Kaiser, M. J. & Mapping stakeholder values for coastal zone management \\
\hline Aldon, Ma. E. T.; Fermin, A. C.; Agbayani, R. F. & $\begin{array}{l}\text { Socio-cultural context of fishers' participation in coastal resources management in Anini-y, } \\
\text { Antique in west central Philippines }\end{array}$ \\
\hline Anilkumar, P. P.; Varghese, K.; Ganesh, L. S. & Formulating a coastal zone health metric for landuse impact management in urban coastal zones \\
\hline $\begin{array}{l}\text { Nogueira de Andrade, M. M.; Szlafsztein, C. F.; Souza-Filho, } \\
\text { P. W. M.; Araujo, A. dos Reis; Tavares Gomes, M. K. }\end{array}$ & $\begin{array}{l}\text { A socioeconomic and natural vulnerability index for oil spills in an Amazonian harbor: A case } \\
\text { study using GIS and remote sensing }\end{array}$ \\
\hline Widmer, W. M.; Reis, R. A. & $\begin{array}{l}\text { An experimental evaluation of the effectiveness of beach ashtrays in preventing marine } \\
\text { contamination }\end{array}$ \\
\hline Pranzini, E.; Simonetti, D.; Vitale, G. & \begin{tabular}{|l|} 
Sand colour rating and chromatic compatibility of borrow sediments \\
\end{tabular} \\
\hline $\begin{array}{l}\text { Garmendia, E.; Gamboa, G.; Franco, J.; Garmendia, J.M.; } \\
\text { Liria, P.; Olazabal, M. }\end{array}$ & Social multi-criteria evaluation as a decision support tool for integrated coastal zone management \\
\hline Vicente, J. A.; Cerezo, R. B. & $\begin{array}{l}\text { The socio-economic contributions of Marine Protected Areas to the fisherfolk of Lingayen Gulf, } \\
\text { Northwestern Philippines }\end{array}$ \\
\hline Coombes, E. G.; Jones, A. P. & $\begin{array}{l}\text { Assessing the impact of climate change on visitor behaviour and habitat use at the coast: A UK } \\
\text { case study }\end{array}$ \\
\hline Ergin, A.; Ozolcer, I. H.; Sahin, F. & $\begin{array}{l}\text { Evaluating coastal scenery using fuzzy logic: Application at selected sites in Western Black Sea } \\
\text { coastal region of Turkey }\end{array}$ \\
\hline Soma, $\mathrm{K}$. & $\begin{array}{l}\text { Framing participation with multicriterion evaluations to support the management of complex } \\
\text { environmental issues }\end{array}$ \\
\hline Pajaro, M. G.; Mulrennan, M. E.; Alder, J.; Vincent, A. C. J. & $\begin{array}{l}\text { Developing MPA effectiveness indicators: Comparison within and across stakeholder groups and } \\
\text { communities }\end{array}$ \\
\hline $\begin{array}{l}\text { Koutrakis, E. T.; Sapounidis, A.; Marzetti, S.; Giuliani, V.; } \\
\text { Martino, S.; Fabiano, M.; Marin, V.; Paoli, C.; Roccatagliata, E.; } \\
\text { Salmona, P.; Rey-Valette, H.; Roussel, S.; Povh, D.; Malvarez, } \\
\text { C. G. }\end{array}$ & Public stakeholders' perception of ICZM and coastal erosion in the Mediterranean \\
\hline Launio, C. C.; Morooka, Y.; Aizaki, H.; liguni, Y. & $\begin{array}{l}\text { Perceptions of small-scale fishermen on the value of marine resources and protected areas: Case } \\
\text { of Claveria, Northern Philippines }\end{array}$ \\
\hline $\begin{array}{l}\text { David, G.; Leopold, M.; Dumas, P. S.; Ferraris, J.; } \\
\text { Herrenschmidt, J. B.; Fontenelle, G. }\end{array}$ & $\begin{array}{l}\text { Integrated coastal zone management perspectives to ensure the sustainability of coral reefs in } \\
\text { New Caledonia }\end{array}$ \\
\hline Brenner, J., Jimenez, J.A., Sarda, R., Garola, A. & $\begin{array}{l}\text { An assessment of the non-market value of the ecosystem services provided by the Catalan } \\
\text { coastal zone, Spain }\end{array}$ \\
\hline Vafaei, F.; Harati, A. N. & Strategic management in decision support system for coastal flood management \\
\hline Wang, X.; Chen, W.; Zhang, L.; Jin, D.; Lu, C. & $\begin{array}{l}\text { Estimating the ecosystem service losses from proposed land reclamation projects: A case study } \\
\text { in Xiamen }\end{array}$ \\
\hline Ko, T.-T.; Chang, Y.-C. & $\begin{array}{l}\text { Integrated marine pollution management: A new model of marine pollution prevention and control } \\
\text { in Kaohsiung, Taiwan }\end{array}$ \\
\hline Liu, X. & Integrated modeling of oil spill respons \\
\hline Liu, X.; Wirtz, K. W. & Managing coastal area resources by stated choice experiments \\
\hline $\begin{array}{l}\text { Horstman, E. M.; Wijnberg, K. M.; Smale, A. J.; Hulscher, S. J. } \\
\text { M. H. }\end{array}$ & On the consequences of a long-term perspective for coastal management \\
\hline $\begin{array}{l}\text { Nobre, A. M.; Musango, J. K.; de Wit, M. P.; Ferreira, J. G. } \\
\text { Knowler, D.:; Philcox, N.; Nathan, S.; Delamare, W.; Haider, } \\
\text { W. Gupta K. }\end{array}$ & \begin{tabular}{|l|} 
A dynamic ecological-economic modeling approach for aquaculture management \\
Assessing prospects for shrimp culture in the Indian Sundarbans: A combined simulation \\
modelling and choice experiment apoporoach
\end{tabular} \\
\hline Bryhn, A. C.; Jimenez, A.; Mateos, A.; Rios-Insua, S. & Multi-attribute analysis of trophic state and waterfowl management in Ringkobing Fjord, Denmark \\
\hline Zita Butardo-Toribio, M.; Alino, P. M.; Guiang, E. S. & Cost-benefit study of Marine Protected Areas: Implications on financing and institutional needs \\
\hline Edwards, P. E. T. & $\begin{array}{l}\text { Sustainable financing for ocean and coastal management in Jamaica: The potential for revenues } \\
\text { from tourist user fees }\end{array}$ \\
\hline Oh, C.-O.; Draper, J.; Dixon, A. W. & Assessing tourists' multi-attribute preferences for public beach access \\
\hline Hills, J.; Carlisle, M.; Le Tissier, M.; Muir, D.; Robinson, C. & Landscape-scale analysis of ecosystem risk and returns: A new tool for ICZM \\
\hline $\begin{array}{l}\text { O'Mahony, C.; Gault, J.; Cummins, V.; Kopke, K.; } \\
\text { O'Suilleabhain, D. }\end{array}$ & $\begin{array}{l}\text { Assessment of recreation activity and its application to integrated management and spatial } \\
\text { planning for Cork Harbour, Ireland }\end{array}$ \\
\hline $\begin{array}{l}\text { Castanedo, S.; Juanes, J. A.; Medina, R.; Puente, A.; } \\
\text { Fernandez, F.; Olabarrieta, M.; Pombo, C. }\end{array}$ & $\begin{array}{l}\text { Oil spill vulnerability assessment integrating physical, biological and socio-economical aspects: } \\
\text { Application to the Cantabrian coast (Bay of Biscay, Spain) }\end{array}$ \\
\hline Petrosillo, l.; Valente, D.; Zaccarelli, N.; Zurli & 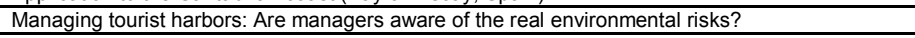 \\
\hline
\end{tabular}

\begin{tabular}{|c|c|c|c|c|c|}
\hline $\begin{array}{l}\text { MARINE ECOLOGY PROGRESS } \\
\text { SERIES }\end{array}$ & 434 & - & 239 & 249 & 2011 \\
\hline FISHERIES RESEARCH & 107 & $1-3$ & 112 & 121 & 2011 \\
\hline $\begin{array}{l}\text { JOURNAL OF ENVIRONMENTAL } \\
\text { MANAGEMENT }\end{array}$ & 91 & 11 & 2172 & 2185 & 2010 \\
\hline $\begin{array}{l}\text { JOURNAL OF ENVIRONMENTAL } \\
\text { MANAGEMENT }\end{array}$ & 91 & 10 & 1972 & 1980 & 2010 \\
\hline $\begin{array}{l}\text { BRAZILIAN ARCHIVES OF BIOLOGY } \\
\text { AND TECHNOLOGY }\end{array}$ & 53 & 5 & 1205 & 1216 & 2010 \\
\hline JOURNAL OF COASTAL RESEARCH & 26 & 5 & 798 & 808 & 2010 \\
\hline OCEAN \& COASTAL MANAGEMENT & 53 & 7 & 385 & 403 & 2010 \\
\hline $\begin{array}{l}\text { INTERNATIONAL JOURNAL OF } \\
\text { ENVIRONMENTAL RESEARCH }\end{array}$ & 4 & 3 & 479 & 490 & 2010 \\
\hline $\begin{array}{l}\text { GLOBAL ENVIRONMENTALL CHANGE- } \\
\text { HUMAN AND POLICY DIMENSIONS }\end{array}$ & 20 & 2 & 303 & 313 & 2010 \\
\hline OCEAN ENGINEERING & 37 & 7 & 583 & 591 & 2010 \\
\hline $\begin{array}{l}\text { ENVIRONMENTAL POLICY AND } \\
\text { GOVERNANCE }\end{array}$ & 20 & 2 & 89 & 106 & 2010 \\
\hline \begin{tabular}{|l|} 
COASTAL MANAGEMENT \\
\end{tabular} & 38 & 2 & 122 & 143 & 2010 \\
\hline \begin{tabular}{|l} 
COASTAL MANAGEMENT \\
\end{tabular} & 38 & 4 & 354 & 377 & 2010 \\
\hline $\begin{array}{l}\text { INTERNATIONAL JOURNAL OF } \\
\text { SUSTAINABLE DEVELOPMENT AND } \\
\text { WORLD ECOLOGY }\end{array}$ & 17 & 5 & 401 & 409 & 2010 \\
\hline \begin{tabular}{|l|} 
MARINE POLLUTION BULLETIN \\
\end{tabular} & 61 & $7-12$ & 323 & 334 & 2010 \\
\hline OCEAN \& COASTAL MANAGEMENT & 53 & - & 27 & 38 & 2010 \\
\hline \begin{tabular}{|l} 
INTERNATIONAL JOURNAL OF \\
ENVIRONMENTAL RESEARCH
\end{tabular} & 4 & 1 & 169 & 176 & 2010 \\
\hline ECOLOGICAL ECONOMICS & 69 & 12 & 2549 & 2556 & 2010 \\
\hline OCEAN \& COASTAL MANAGEMENT & 53 & 10 & 624 & 635 & 2010 \\
\hline ENVIRONMENTAL SCIENCE \& POLICY & 13 & 5 & 415 & 422 & 2010 \\
\hline $\begin{array}{l}\text { ESTUARINE COASTAL AND SHELF } \\
\text { SCIENCE }\end{array}$ & 86 & 3 & 512 & 517 & 2010 \\
\hline OCEAN \& COASTAL MANAGEMENT & 52 & 12 & 593 & 611 & 2009 \\
\hline ECOLOGICAL ECONOMICS & 68 & 12 & 3007 & 3017 & 2009 \\
\hline MARINE POLICY & 33 & 4 & $\frac{613}{613}$ & 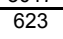 & 2009 \\
\hline $\begin{array}{l}\text { JOURNAL OF ENVIRONMENTAL } \\
\text { MANAGEMENT }\end{array}$ & 90 & 8 & 2568 & 2577 & 2009 \\
\hline $\begin{array}{l}\text { PHILIPPINE AGRICULTURAL } \\
\text { SCIENTIST }\end{array}$ & 92 & 2 & 153 & 169 & 2009 \\
\hline MARINE POLICY & 33 & 2 & 376 & 385 & 2009 \\
\hline $\begin{array}{l}\text { COASTAL MANAGEMENT } \\
\end{array}$ & 37 & 2 & 119 & 135 & 20 \\
\hline MARI & 33 & 6 & 887 & 900 & \\
\hline MARINE POLICY & 33 & $\frac{6}{6}$ & 930 & 937 & 2009 \\
\hline $\begin{array}{l}\text { JOURNAL OF ENVIRONMENTAL } \\
\text { MANAGEMENT }\end{array}$ & 91 & 1 & 149 & 159 & 2009 \\
\hline & 58 & 10 & 1454 & 1461 & 2009 \\
\hline OCE & 52 & & 493 & & \\
\hline
\end{tabular}


\begin{tabular}{|l}
\hline Nobre, A. M. \\
\hline Marin, V.P. \\
\hline Zng.
\end{tabular} \begin{tabular}{l}
\hline Marin, V.; Palmisani, F.; Ivaldi, R.; Dursi, R.; Fabiano, M. \\
\hline Zhai, G.; Suzuki, T.
\end{tabular}

Vella, P.; Bowen, R. E.; Frankic, A.

Jurado, E.; Gutto Dantas, A.; Pereira da Silva, C.

Lazarow, N.

Alves, F.; Roebeling, P.; Pinto, P.; Batista, P.

Martins, F.; de Almeida, A. B.; Pinho, L.

\begin{tabular}{l} 
Mercado, V; Malvarez, G.; Albuquerque, F.; Navas, F. \\
\hline
\end{tabular}

Souto, R. D.; Polette, M.; Kampel, M.

Zhai, G.; Suzuki, T.

Marfai, M. A.; King, L.

Lloret, J.; Zaragoza, N.; Caballero, D.; Riera, V.

Tudor, D. T.: Williams, A. T.

Roca, E.; Gamboa, G.; Tabara, J. D.

Meur-Ferec, C.; Deboudt, P.; Morel, V.

\begin{tabular}{ll} 
Karaca, M.; Nich \\
\hline Devoy, R. J. N. \\
\hline
\end{tabular}

de la Vega-Leinert, A. C.; Nicholls, R. J.
D.

\begin{tabular}{l} 
Michler-Cieluch, T.; Kodeih, S. \\
\hline Stal, J.; Paulsen, S.; Pihl, L.; Ronnback, P.; Soderqvist, T.;
\end{tabular}

Wennhage, $H$

za, N.: Caballero, D.: Riera $V$.

Few, R.; Brown, K

\begin{tabular}{l}
\hline Maliao, R. J.; Polohan, B. B. \\
\hline Chang, Y. C.; Hong, F. W.; Lee, M. T.
\end{tabular}

Turner, R. K.; Burgess, D.; Hadley, D.; Coombes, E.; Jackson

Shepherd, D.; Burgess, D.; Jickells, T.; Andrews, J.; Cave, R.; Turner, R. K.; Aldridge, J.; Parker, E. R.; Young, E.

Agueero, M.; Claveri, M.

Zoppi, $C$

Smith, M. K. S.; King, C. M.; Sauer, W. H. H.; Cowley, P. D.

Rangel, M. O.; Erzini, K.

Goeldner-Gianella, L.

\begin{tabular}{l}
\hline Fletcher, S.; Pike, K. \\
\hline Majanen $\mathrm{T}$. \\
\hline
\end{tabular}

Whitfield, R.: Roche R.

Samonte-Tan, G. P. B.; White, A. T.; Tercero, M. A.; Diviva, J. Tabara, E.; Caballes, $\mathrm{C}$.

Lazarow, $N$

Alves, F. L.; da Silva, C. P.; Pinto, P.
An ecological and economic assessment methodology for coastal ecosystem management Users' perception analysis for sustainable beach management in Italy measure An evolving protocol to identify key stakeholder-influenced indicators of coastal change: The case of Marine Protected Areas capacity (Costa del Sol - Spain Using observed market expenditure to estimate the value of recreational surfing to the Gold Valung ecosystem service losses from coastal erosion using a benefits transfer approach: A case study for the Central Portuguese coast (1) Impact of the changing economic models in the development of societal and environmental structures of coastal natural parks

Public willingness to pay for icators for the coastal zone of Rio de Janeiro, Brazil development: Evidence from $T$ vironmental management, risk reduction and economic Coastal flood management in Semarang, Indonesia

Biological and socioeconomic implications of recreational boat fishing for the management of fishery resources in the marine reserve of Cap de Creus (NW Mediterranean) Assessing the multidimensionality of coastal erosion risks: Public participation and multicriteria analysis in a Mediterranean coastal system

Coastal risks in France: An integrated method for evaluating vulnerability

Coastal vulnerability ond the implications of sea-level rise for Ireland Potential implications of sea-level rise for Great Britain

Mussel and seaweed cultivation in offshore wind farms: An opinion survey fisheries management

Impacts of recreational boating on the marine environment of Cap de Creus (Mediterranean Sea) Scenario-based stakeholder engagement: Incorporating stakeholders preferences into coastal

\begin{tabular}{l} 
planning for climate change \\
Evaluating the impacts of mangrove rehabilitation in Cogtong Bay, Philippines \\
\hline A system dynamic based DSS for sustainable coral reef management in Kenting coastal zone,
\end{tabular} Taiwan

A cost-benefit appraisal of coastal managed realignment policy

Modelling the effects and economics of managed realignment on the cycling and storage of

nutrients, carbon and sediments in the Blackwater estuary $\mathrm{UK}$
A model for evaluating the socioeconomic performance of alternative management policies in coastal zones: Application to Patos Lagoon (Brazil) and the Jucar River Estuary (Spain)

Development of fishery indicators for local management initiatives - a case study for Plettenberg Bay, South Africa

An assessment of catches and harvest of recreational shore angling in the north of Portugal

Perceptions and attitudes toward de-polderisation in Europe: A comparison of five opinion

Coastal management in the Solent: The stakeholder perspective

UK personal watercraft management: A user perspective

Economic valuation of coastal and marine resources: Bohol Marine Triangle, Philippines

The value of coastal recreational resources: A case study approach to examine the value of recreational surfing to specific locales The assessment of the coastal zone development at a regional level - the case study of Portugal
Central Area \begin{tabular}{|l|l|l|l|l|l|}
\hline ENVIRONMENTAL MANAGEMENT & 44 & 1 & 185 & 204 & 2009 \\
\hline
\end{tabular} \begin{tabular}{l|c|c|c|c|c|}
\hline OCEAN \& COASTAL MANAGEMENT & 52 & 5 & 268 & 277 & 2009 \\
\hline WATER RESOURCL & & &
\end{tabular} \begin{tabular}{|l|l|l|l|l|l|l|}
\hline ICES JOURNAL OF MARINE SCIENCE & 66 & 1 & 203 & 213 & 2009 \\
\hline
\end{tabular} JOURNAL OF COASTAL RESEARCH JOURNAL OF COASTAL RESEARCH JOURNAL OF COASTAL RESEARCH JOURNAL OF COASTAL RESEARCH JOURNAL OF COASTAL RESEARCH JOURNAL OF COASTAL RESEARCH CHINA ECONOMIC REVIEW \begin{tabular}{|l|c|c|c|c|c|}
\hline ENVIRONMENTAL GEOLOGY & 55 & 7 & 1507 & 1518 & 2008 \\
\hline FISHERIES RESEARCH & 91 & $2-3$ & 252 & 259 & 2008 \\
\hline
\end{tabular} \begin{tabular}{|c|c|c|c|c|}
\hline 91 & $2-3$ & 252 & 259 & 2008 \\
\hline
\end{tabular} \begin{tabular}{|l|c|c|c|c|c|c|}
\hline & & & & & \\
\hline RISK ANALYSIS & 24 & 3 & 735 & 745 & 2008 \\
\hline & 28 & 2 & 399 & 412 & 2008 \\
\hline
\end{tabular}

JOURNAL OF COASTAL RESEARCH JOURNAL OF COASTAL RESEARCH JOURNAL OF COASTAL RESEARCH OCEAN \& COASTAL MANAGEMENT

OCEAN \& COASTAL MANAGEMENT JOURNAL OF ENVIRONMENTAL MANAGEMENT ECOLOGICALMLTEANAGEMEN

GLOBAL ENVIRONMENTAL CHANGEHUMAN AND POLICY DIMENSIONS ESTUARINE COASTAL AND SHELF

JOURNAL OF COASTAL RESEARCH

LAND USE POLICY SCIENCE FISHERIES MANAGEMENT AND JOUROGY MARINE POLICY MARINE POLICY COASTAL MANAGEMENT JOURNAL OF COASTAL RESEARCH

JOURNAL OF COASTAL RESEARCH JOURNAL OF COASTAL RESEARCH

\begin{tabular}{l|l}
\hline 73 & $3-4$ \\
\hline
\end{tabular}

\begin{tabular}{|l|l|}
\hline 24 & 2 \\
\hline 29 & 3
\end{tabular}


Mangi, S. C.; Roberts, C. M.; Rodwell, L. D. Brenner, J.; Jimenez, J. A.; Sarda, R.

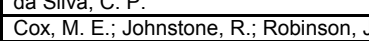
\begin{tabular}{l} 
Gomez, S.; Lloret, J.; Demestre, M.; Riera, V. \\
\hline Gome,
\end{tabular} Damodaran, A.

\begin{tabular}{|l}
\hline Dall'Aste Brandolini, S. M. \\
\hline Sobhe
\end{tabular} Gobhee, S.K. K.

Andrews, J. E.; Burgess, D.; Cave, R. R.; Coombes, E. G.; \begin{tabular}{l} 
White, A.; Deguit, E.; Jatulan, W.; Eisma-Osorio, L. \\
\hline Liu.
\end{tabular} Peng, B.R.; Hong, H.S.; Xue, X.Z; Jin, D.

Ledoux, L.; Beaumont, N.; Cave, R.; Turner, R. K. Ledoux, L; Cornell, S.; O'Riordan, T.; Harvey, R.; Banyard, L. Lamberti, A.; Zanuttigh, B.

Nunneri, C.; Hofmann, J.

Christie, P.

Sievanen, L.; Crawford, B.; Pollnac, R.; Lowe, C.

Pomeroy, R.S.; Oracion, E.G.; Pollnac, R.B.; Caballes, D.A. \begin{tabular}{|l}
\hline Oracion, E.G.; Miller, M.L.; Christie, P. \\
\hline Hines, E.; Adulyanukosol, K.; Duffus, D.; Dearden, P.
\end{tabular}

\section{Cho, D.O.}

Pirrone, N.; Trombino, G.; Cinnirella, S.; Algieri, A.; Bendoricchio, G.; Palmeri, L.

Karageorgis, A. P..; Skourtos, M. S. 'Kapsimalis, V. Kontogianni, A. D.; Skoulikidis, N. T.; Pagou, K.; Nikolaidis, N.

Sarda, R.; Avila, C.; Mora, J.

\begin{tabular}{|l}
\hline Winfield, P.G. \\
\hline Gabr, H.S. \\
\hline Chr, \\
\hline
\end{tabular}

Chuenpagdee, R.; Fraga, J.; Euan-Avila, J.

Webb, E.L.; Maliao, R.J.; Siar, S.V.

Perez-Sanchez, E.; Muir, J.F.

Glaser, M.; Berger, U.; Macedo, R.

Tudor, D. T.; Williams, A. T.

Alessa, L.; Bennett, S.M.; Kliskey, A.D.

Krause, G.; Glaser, M.

McGlashan, D.J.; Firn, J.R.

MacLeod, M.; da Silva, C.P.; Cooper, J.A.G.
Reef fisheries management in Kenya: Preliminary approach using the driver-pressure-stateimpacts-response (DPSIR) scheme of indicators

Definition of homogeneous environmental management units for the Catalan coast

Landscape perception and coastal management: A methodology to encourage public participation Relationships between perceived coastal waterway condition and social aspects of quality of life (Cape Creus)

Coastal resource complexes of South India: Options for sustainable management

Investing in biodiversity: The recreational value of a natural coastal area Fisheries biodiversity conservation and sustainable tourism in Mauritius Fishing for responses: A local experts consultation approach on the Brazilian sardine fishery sustainability

Biogeochemical value of managed realignment, Humber estuary, UK

Integrated coastal management in Philippine local governance: Evolution and benefit

On the measurement of socioeconomic benefits of integrated coastal management (ICM):

Application to Xiamen, China

Scenarios for integrated river catchment and coastal zone management

Towards sustainable flood and coastal management: Identifying drivers of, and obstacles to, managed realignment

An integrated approach to beach management in Lido di Dante, Italy

A participatory approach for Integrated River Basin Management in the Elbe catchment

Observed and perceived environmental impacts of Marine Protected Areas in two Southeast Asia sites

Weeding through assumptions

Perceived economic factors influencing the sustainability of integrated coastal management projects in the Philippines

Marine protected areas for whom? Fisheries, tourism, and solidarity in a Philippine community Andaman coast of Thailand

Lessons learned from Lake Shiwha project zone management: preliminary application to the Po catchment-Adriatic Sea coastal zone system An integrated approach to watershed management within the DPSIR framework: Axios River catchment and Thermaikos Gulf

A methodological approach to be used in integrated coastal zone management processes: The case of the Catalan Coast (Catalonia, Spain)

Brighton Marina to Ovingdean Gap coast-protection scheme

Perception of urban waterfront aesthetics along the Nile in Cairo, Egyp

Using local user perceptions to evaluate outcomes of protected area management in the Sagay Marine Reserve, Philippines

mecoacan Local vulnerability as an adva

antage: Mangrove forest management in Para state, north Brazil, under conditions of illegality

Public perception and opinion of visible beach aesthetic pollution: The utilisation of photography behaviors in the intertidal zone of Pacific Rim National Park and Reserve behaviors in the interlidal zone of Pacific Rim National Pank and Reserve Braganga region (Para, North Brazil)

Perceived socio-economic and environmental costs and benefits of ICZM in Scotland

A comparative study of the perception and value of beaches in rural Ireland and Portugal: Implications for coastal zone managemen \begin{tabular}{|l|c|c|c|c|c|}
\hline OCEAN \& COASTAL MANAGEMENT & 50 & $5-6$ & 463 & 480 & 2007 \\
\hline
\end{tabular} \begin{tabular}{|l|c|c|c|c|c|c|} 
& & & & & & \\
\hline ENVIRONMENTAL MANAGEMENT & 38 & 6 & 993 & 1005 & 2006 \\
\hline
\end{tabular}

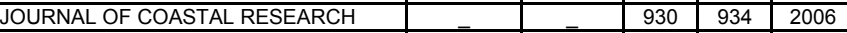
COASTAL MANAGEMENT JOURNAL OF ENVIRONMENTAL OCOAN JOURNAL OF COASTAL RESEARCH SCIENCE OF THE TOTAL \begin{tabular}{|l|c|c|c|c|c|}
\hline COASTAL MANAGEMENT & 34 & 3 & 287 & 302 & 2006 \\
\hline JOURNAL OF HAZARDOUS MATERIALS & 134 & $1-3$ & 27 & 35 & 2006 \\
\hline
\end{tabular} \begin{tabular}{|l|c|c|c|c|c|}
\hline OCEAN \& COASTAL MANAGEMENT & 49 & $3-4$ & 93 & 109 & 2006 \\
\hline
\end{tabular}

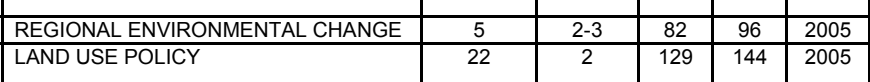
\begin{tabular}{|l|l|l|l|l|l|l|}
\hline ESTUARINE COASTAL AND SHELF & 62 & 3 & 441 & 451 & 2005 \\
\hline
\end{tabular} SCIENCE

SCIUARINE COASTAL AND SHELF

SCIENCE OCEAN \& COASTAL MANAGEMENT OCEAN \& COASTAL MANAGEMENT OCEAN \& COASTAL MANAGEMENT ENVIRONMENTAL MANAGEMENT

COASTAL MANAGEMENT

REGIONAL ENVIRONMENTAL CHANGE

REGIONAL ENVIRONMENTAL CHANGE

ESTUARINE COASTAL AND SHELF SCIENCE

\begin{tabular}{|l|c|c|c|c|c|} 
& & & 427 & 430 & \\
\hline WATR AND ENVIRONMENT JOURNAL & 18 & 3 & 166 & 170 & 2004 \\
\hline
\end{tabular}

\begin{tabular}{|l|l|l|l|l|l|}
\hline COASTAL MANAGEMENT & 32 & 2 & 155 & 171 & 2004 \\
\hline
\end{tabular}

SOCIETY Q NATURAL RESOURCES CENDCOASTAL MANAGEMENT OCEAN \& COASTAL MANAGEMENT REGIONAL ENVIRONMENTAL CHANGE JOURNAL OF COASTAL RESEARCH JOURNAL OF ENVIRONMENTAL OCEAN \& COASTAL MANAGEMENT

SCOTTISH GEOGRAPHICAL JOURNAL JOURNAL OF COASTAL RESEARCH

\begin{tabular}{|c|c|c|c|c|}
\hline 62 & 3 & 521 & 537 & 2005 \\
\hline 48 & $3-6$ & 252 & 270 & 2005 \\
\hline 48 & $3-6$ & 297 & 313 & 2005 \\
\hline
\end{tabular}

\begin{tabular}{|c|c|c|c|c|}
\hline 48 & $3-6$ & 360 & 377 & 2005 \\
\hline
\end{tabular}

\begin{tabular}{|c|c|c|c|c|}
\hline 48 & $3-6$ & 393 & 410 & 2005 \\
\hline 36 & 5 & 654 & 664 & 2005 \\
\hline
\end{tabular}

\begin{tabular}{|c|c|c|c|c|}
\hline 33 & 3 & 315 & 334 & 2005 \\
\hline 5 & $2-3$ & 111 & 137 & 2005 \\
\hline
\end{tabular}

.

\begin{tabular}{|l|l|l|l|l|}
\hline 17 & 2 & 147 & 161 & 2004 \\
\hline 31 & 2 & 138 & 148 & 2004 \\
\hline
\end{tabular}

\begin{tabular}{|l|l|l|l|l|l|}
\hline 46 & $6-7$ & 681 & 700 & 2003 \\
\hline
\end{tabular}

19
\begin{tabular}{|l|l|l|l|l|}
\hline 19 & 4 & 1104 & 1115 & 2003 \\
\hline 68 & 2 & 207 & 218 & 2003 \\
\hline
\end{tabular} \begin{tabular}{|c|c|c|c|c|}
\hline & & 207 & 218 & 2003 \\
\hline 46 & $9-10$ & 859 & 874 & 2003 \\
\hline
\end{tabular} \begin{tabular}{|c|c|c|c|c|}
\hline 119 & 2 & 103 & 119 & 2003 \\
\hline 18 & 1 & 14 & 24 & 2002 \\
\hline
\end{tabular} 


\section{Armitage, D.}

Courtney, C.A.; White, A.T. Dequit Johnston, R.J;: Grigalunas, T.A.; Opaluch, J.J.; Mazzotta, M. Foucat, V.S.A.

Arhonditsis, G.; Karydis, M.; Tsirtsis, G.

White, A.T.; Courtney, C.A.; Salamanca, A. Munoz-Perez, J.J.; Roman-Blanco, B.L.D.; Gutierrez-Mas, M.; Moreno, L.; Cuena, G.J.

Chuenpagdee, R.; Knetsch, J.L.; Brown, T.C. de Kok, J.L.; Engelen, G.; White, R.; Wind, H.G.

\section{Hugues-Dit-Ciles, E.K.}

Thumerer, T.; Jones, A.P.; Brown, D.

\section{Fernandes, L.; Ridgley, M.A.; van't Hof, T.}

Hareau, A.; Hofstadter, R.; Saizar, A.

Morgan. $R$.

Pet-Soede, C.; Cesar, H.S.J.; Pet, J.S.

Hertling, U.M.; Lubke, R.A.

\begin{tabular}{l} 
van den Belt, M.; Deutsch, L.; Jansson, A. \\
\hline Kawle,
\end{tabular} Kawabe, $\mathrm{M}$

Tunstall, S.M.; Penning-Rowsell, E.C. DeRuyck. M.C.: Soares, A.G.; McLachlan, A. Zeidler, R. B.

Knecht, R.W.; Cicin-Sain, B.; Fisk, G.W.

\begin{tabular}{l} 
Knecht, R.W.; Cicin-Sain, B.; Fisk, G.W. \\
\hline
\end{tabular} Moriki, A.; Coccossis, H.; Karydis, M. \begin{tabular}{l} 
Cooper, J.A.G., Ramm, A.E.L.; \\
\hline Flood, S.; Cocklin, C.; Parnell, K. \\
\hline
\end{tabular}
Socio-institutional dynamics and the political ecology of mangrove forest conservation in Central Sulawesi, Indonesia

Building Philippine local government capacity for coastal resource management

Valuing estuarine resource services using economic and ecological models:The Peconic Estuary System study Community-based ecotourism management moving towards sustainability, in Ventanilla, Oaxaca matheling and multicriteria methods in assessing environmental

Experience with marine protected area planning and management in the Philippines

Coastal defence and the Habitats Directive: Predictions of habitat change in England and Wales maintenance in the Gulf of Cadiz (SW Spain) Coastal management using public judgments, importance scales, and predetermined schedule

Modeling land-use change in a decision-support system for coastal-zone management Developing a sustainable community-based aquaculture plan for the lagoon of Cuyutlan through a public awareness and involvement process

ystem for climate change associated flood risk assessment

Multiple criteria analysis integrates economic, ecological and social objectives for coral reef managers

Vulnerability to climate change in Uruguay: Potential impacts on the agricultural and coast resource sectors and response capabilities

\begin{tabular}{l} 
A novel, user-based rating system for tourist beaches \\
An economic analysis of blast fishing on Indonesian coral reefs \\
\hline Preferences and priorities of recreational beach users in Wales, UK
\end{tabular}

Use of Ammophila arenaria for dune stabilization in South Africa and its current distribution Perceptions and problems

A consensus-based simulation model for management in the Patagonia Coastal Zone

To enhance the environmental values of Tokyo Bay - a proposition for integrated coastal zone management

The English beach: Experiences and values
Social carrying capacity as a management tool for sandy beaches

Climate change vulnerability and response strategies for the coastal zone of Poland Start with what the people know: A community based approach to integrated coastal zon management

Perceptions of the performance of state coastal zone management programs in the United States. 2. Regional and state comparisons

Perceptions of the performance of state coastal zone management programs in the United States

The estuarine health index $-\mathrm{A}$ new approach to scientific-information transfer

Coastal resource management conflicts and community action at Mangawhai, New Zealand
GLOBAL ENVIRONMENTAL CHANGEHUMAN AND POLICY DIMENSIONS COASTAL MANAGEMENT

OCEAN \& COASTAL MANAGEMENT JOURNAL OF COASTAL RESEARCH COASTAL MANAGEMENT COASTAL ENGINEERING COASTAL MANAGEMENT JOURNAL OF COASTAL RESEARCH ENVIRONMENTAL MONITORING AND ASSESSMENT

INTERNATIONAL JOURNAL OF SCIENCE CORAL REEFS

CLIMATE RESEARCH TOURISM MANAGEMENT ENVIRONMENTAL CONSERVATION JOURNAL OF COASTAL RESEARC ENVIRONMENTAL MANAGEMENT ECOLOGICAL MODELLING OCEAN \& COASTAL MANAGEMENT GEOGRAPHICAL JOURNAL JOURNAL OF COASTAL RESEARCH COASTAL MANAGEMENT COASTAL MANAGEMENT OOURNAL OF COASTAL RESEARCH COASTAL MANAGEMENT

\begin{tabular}{|c|c|c|c|c|}
\hline 12 & 3 & 203 & 217 & 2002 \\
\hline 30 & 1 & 27 & 45 & 2002 \\
\hline 30 & 1 & 47 & 65 & 2002 \\
\hline 45 & 8 & 511 & 529 & 2002 \\
\hline 18 & 4 & 698 & 711 & 2002 \\
\hline 30 & 1 & 1 & 26 & 2002 \\
\hline 167 & & 39 & 56 & 2001 \\
\hline 42 & 2 & 143 & 153 & 2001 \\
\hline 29 & 4 & 253 & 270 & 2001 \\
\hline 17 & 3 & 636 & 644 & 2001 \\
\hline 6 & 2 & 123 & 132 & 2001 \\
\hline 28 & 4 & 365 & 383 & 2000 \\
\hline 14 & 3 & 265 & 281 & 2000 \\
\hline 18 & 4 & 393 & 402 & 1999 \\
\hline 12 & $2-3$ & 185 & 193 & 1999 \\
\hline 20 & 4 & 393 & 410 & 1999 \\
\hline 26 & 2 & 83 & 93 & 1999 \\
\hline 15 & 3 & 653 & 667 & 1999 \\
\hline 24 & 4 & 467 & 482 & 1999 \\
\hline 110 & 1 & 79 & 103 & 1998 \\
\hline 41 & 1 & 19 & 39 & 1998 \\
\hline 164 & & 319 & 332 & 1998 \\
\hline 13 & 3 & 822 & 830 & 1997 \\
\hline 36 & $1-2$ & 151 & 173 & 1997 \\
\hline 36 & $1-3$ & 167 & 203 & 1997 \\
\hline 25 & 3 & 325 & 343 & 1997 \\
\hline 24 & 2 & 141 & 163 & 1996 \\
\hline 12 & 1 & 171 & 178 & 1996 \\
\hline 25 & 2 & 103 & 141 & 1994 \\
\hline
\end{tabular}




\section{Supplement 2. Categories used for classification}

2.1. Coastal issues

\begin{tabular}{|c|c|}
\hline \multirow{4}{*}{ Coastal hazards } & Erosion, flooding (including sea-level rise) \\
\hline & Climate change (changing weather: heavy rainstorm, heatwave) \\
\hline & Tsunami \\
\hline & Massive (accidental) pollution (oil or chemical spills) \\
\hline \multirow{5}{*}{ Environmental degradation } & Natural area destruction/loss of biodiversity (invasive species, endangered species loss, habitat loss) \\
\hline & Urban sprawl, land reclamation \\
\hline & Landscape/seascape quality (marine and terrestrial litter/dumping, etc.) \\
\hline & Overexploitation of resources (over-fishing and destructive fishing, mineral extraction, saline intrusion, water shortage, soil exhaustion) \\
\hline & Chronic pollution of the environment (organic and chemical effluents, microbiological contamination, minor spills, and air pollution) \\
\hline \multirow{5}{*}{ Coastal economy, livelihood (of coastal communities) } & Employment opportunities \\
\hline & Alternative livelihoods \\
\hline & Coastal development \\
\hline & Development of urban waterfronts, regeneration of traditional seaside resorts \\
\hline & Energy development (renewable, etc.) \\
\hline \multirow{5}{*}{ Coastal amenities, welfare } & Recreational activities \\
\hline & Access to the coast, social equity in coastal planning \\
\hline & User conflicts \\
\hline & Local identity, provisions for traditional users and uses \\
\hline & Landscape and heritage protection \\
\hline
\end{tabular}




\begin{tabular}{|c|c|c|}
\hline \multirow[t]{3}{*}{ Survey } & Survey & $\begin{array}{l}\text { List of questions asked of a specific category of people or community and designed to produce original informations (where the desired data do not } \\
\text { exist or are not available). }\end{array}$ \\
\hline & Opinion survey & $\begin{array}{l}\text { "A sample survey which aims at ascertaining or elucidating opinions possessed by the members of a given human population with regard to certain } \\
\text { topics" (OCDE, glossary of statistical terms, http://stats.oecd.org/glossary/detail.asp?ID=3772). }\end{array}$ \\
\hline & $\begin{array}{l}\text { Socio-economic } \\
\text { survey }\end{array}$ & $\begin{array}{l}\text { A sample survey aimed at getting socio-economic information about a given human population with regard to certain topics (income level, gender, } \\
\text { educational level, location and family size, employment, resource dependence, etc.). }\end{array}$ \\
\hline \multicolumn{2}{|c|}{$\begin{array}{l}\text { Monetary valuation (or partial } \\
\text { economic evaluation) }\end{array}$} & $\begin{array}{l}\text { Evaluations that address costs or outcomes. This category encompasses information related to valuation of goods and services. Economic valuation } \\
\text { of recreational uses or ecosystem goods and services falls into this category. }\end{array}$ \\
\hline \multicolumn{2}{|c|}{ Spatial data analysis } & "In broad terms one might define spatial analysis as the quantitative study of phenomena that are located in space" (Bailey and Gatrell, 1995, p. 7). \\
\hline \multicolumn{2}{|c|}{ Trend analysis } & $\begin{array}{l}\text { Trend analysis is the practice of collecting information and attempting to spot a pattern, or trend, in the information. Trend analysis is used to predict } \\
\text { future events but can be used to estimate uncertain events in the past (Esterby, 1993). }\end{array}$ \\
\hline \multirow[t]{2}{*}{$\begin{array}{l}\text { Scenario, } \\
\text { prospective }\end{array}$} & Scenarios & $\begin{array}{l}\text { "Scenario can denote both descriptions of possible future states and descriptions of developments" (Börjeson et al., 2006, p. 723). "Scenarios portray } \\
\text { images of how society and its supporting environment could look, given different sets of assumptions and consequent conditions" (Ledoux et al., } \\
2005, \text { p. 87). }\end{array}$ \\
\hline & $\begin{array}{l}\text { Prospective } \\
\text { simulation }\end{array}$ & $\begin{array}{l}\text { Prospective simulation is the modeling of changes induced by the different defined scenarios. It is the process of applying a statistical model or data } \\
\text { mining algorithm to data for the purpose of producing (exploring or predicting) new or future observations under different conditions (Shmueli, 2010). }\end{array}$ \\
\hline \multicolumn{2}{|c|}{ Explanatory modeling } & Statistical models used for testing causal explanations with observational data (correlation tests, regression models, etc.: Shmueli, 2010). \\
\hline \multicolumn{2}{|c|}{ Indicator system } & $\begin{array}{l}\text { Indicators are a limited set of issue-related parameters (quantitative/qualitative statements or measured/observed parameters) that can be used to } \\
\text { describe existing situations (the dynamic state of a coastal system) and measure changes or trends over time. Their three main functions are } \\
\text { simplification, quantification, and communication. Indicators generally simplify in order to quantify complex phenomena so that communication of } \\
\text { information to policy-makers and other interested parties, including the general public, is enabled or enhanced (UNESCO, 2006). }\end{array}$ \\
\hline \multirow[t]{3}{*}{$\begin{array}{l}\text { CEA or CBA } \\
\text { (full economic } \\
\text { valuation) }\end{array}$} & $\begin{array}{l}\text { Full economic } \\
\text { valuation }\end{array}$ & $\begin{array}{l}\text { Drummond et al. (1987) define an economic evaluation as the comparative analysis of alternative courses of action in terms of both their costs and } \\
\text { consequences. Both resource inputs (economic costs) and downstream resource savings (economic benefits) are measured and included in all types } \\
\text { of economic evaluations (i.e., in either a CEA or CBA). An evaluation that considers both costs and outcomes, and compares two or more programs, } \\
\text { is considered to be a full economic evaluation. }\end{array}$ \\
\hline & CEA & $\begin{array}{l}\text { The cost-effectiveness analysis (CEA) "assesses the impact of different options in physical terms, and compares these to the costs of the different } \\
\text { options to determine which option, or mix of options, achieves the target at least cost" (Ledoux and Turner, 2002, p. 591). }\end{array}$ \\
\hline & CBA & $\begin{array}{l}\text { The cost-benefits analysis (CBA) values all costs and benefits in monetary terms to establish a stream of costs and benefits associated with a } \\
\text { particular policy over time and to compare these to the costs of the different options to determine which option, or mix of options, achieves the target } \\
\text { at least cost (Ledoux and Turner, 2002). }\end{array}$ \\
\hline \multicolumn{2}{|c|}{ Multi-criteria analysis } & $\begin{array}{l}\text { "Multi-criteria analysis is a method of choosing between a set of alternative options on the basis of a set of defined evaluation criteria" (Brown et al., } \\
\text { 2001, p. 14). "Policy options are compared by reference to an explicit set of evaluation criteria, which can include both quantitative (monetary or not) } \\
\text { and qualitative data, together with a weighting scheme" (Ledoux and Turner, 2002, p. 592). }\end{array}$ \\
\hline \multicolumn{2}{|c|}{ Participatory approach } & $\begin{array}{l}\text { The public's and stakeholder' participation in the coastal zone management process encompasses different purposes and consequently exhibits } \\
\text { different levels of inclusion. Momtaz and Gladstone (2008) include in the objectives of public participation "sharing information, involving the } \\
\text { community at an early stage of decision making, taking community aspirations into consideration and giving the community the ability to influence the } \\
\text { outcome of decision making" (p. 223). According to Brown et al. (2001), the most basic participation level is passive consultation (information is } \\
\text { disseminated to inform people impacted by future management plans) and the most active participation level involves stakeholders in sharing power } \\
\text { and actual management (collegial). For the purpose of this paper, we only include high levels of participation such as the participatory approach. }\end{array}$ \\
\hline \multicolumn{2}{|c|}{ Descriptive statistics } & $\begin{array}{l}\text { Descriptive statistics summarize population data by describing what was observed in the sample numerically or graphically. Numerical descriptors } \\
\text { include mean and standard deviation for continuous data types, while frequency and percentage are more useful for describing categorical data. }\end{array}$ \\
\hline
\end{tabular}


2.3. Socio-economic information

\begin{tabular}{|l|l|}
\hline \multirow{3}{*}{ Coastal population } & Demographic \\
\cline { 2 - 2 } & Livelihood \\
\hline \multirow{4}{*}{ Coastal use intensity } & Frequentation \\
\cline { 2 - 2 } & Infrastructures \\
\cline { 2 - 2 } & Land use classification \\
\cline { 2 - 2 } & Production and consumption of goods and services \\
\hline \multirow{3}{*}{ Monetary value } & Main concerns \\
\cline { 2 - 2 } & Responses (alternatives, perceived impacts) \\
\cline { 2 - 2 } & Market uses \\
\cline { 2 - 2 } Coastal activities & Ecosystem services (other) \\
\cline { 2 - 2 } & Economic indicators (added value, investment) \\
\hline \multirow{2}{*}{ Management } & Other (infrastructures, production and consumption of goods and services) \\
\cline { 2 - 2 } & Management costs \\
\hline
\end{tabular}

${ }^{*}$ Cultural ecosystem services: ecosystem services from which people derive non-material

(e.g., recreational, educational, aesthetic, cultural) benefits (Millennium Ecosystem Assessment, 2005)

\section{References}

Bailey, T. C., Gatrell, A. C., 1995. Interactive Spatial Data Analysis. Longman, Harlow-New York, 413 pp.

Börjeson, L., Höjer, M., Dreborg, K. H., Ekvall, T., Finnveden, G., 2006. Scenario types and techniques: Towards a user's guide. Futures 38, 723-739.

Brown, K., Tompkins, E., Adger, W. N., 2001. Trade-off analysis for participatory coastal zone decision-making. Overseas Development Group, Centre for Social and Economic Research on the Global Environment, University of East Anglia, Norwich, 109 pp.

Drummond, M. F., Stoddart, G. L., Torrance, G. W., 1987. Methods for the Economic Evaluation of Health Care Programmes. Oxford University Press, Oxford, New York, 305 pp.

Esterby, S. R., 1993. Trend analysis methods for environmental data. Environmetrics, 4 (4), 459-481.

Ledoux, L., Beaumont, N., Cave, R., Turner, R. K., 2005. Scenarios for integrated river catchment and coastal zone management. Regional Environmental Change 5, 82-96.

Ledoux, L., Turner, R. K., 2002. Valuing ocean and coastal resources: A review of practical examples and issues for further action. Ocean \& Coastal Management 45, 583-616.

Millennium Ecosystem Assessment, 2005. Ecosystems and human well-being: Synthesis. Island Press, Washington DC., 137 pp.

Momtaz, S., Gladstone, W., 2008. Ban on commercial fishing in the estuarine waters of New South Wales, Australia: Community consultation and social impacts. Environmental Impact Assessment Review 28, 214-225.

Shmueli, G., 2010. To explain or to predict? Statistical Science 25 (3), 289-310.

UNESCO, 2006. A handbook for measuring the progress and outcomes of integrated coastal and ocean management. IOC, UNESCO Publishing, Paris, 224 pp. 


\section{Supplement 3. Detailed statistical analysis}

3.1. Bibliographical and geographical characteristics

3.1.1. Journals (expressed as a percentage of the total number of papers, $n=170$ )

\begin{tabular}{|c|c|}
\hline \multicolumn{2}{|l|}{ JOURNAL OF COASTAL RESEARCH } \\
\hline OCEAN \& COASTAL MANAGEMENT & $17.6 \%$ \\
\hline COASTAL MANAGEMENT & $10.6 \%$ \\
\hline JOURNAL OF ENVIRONMENTAL MANAGEMENT & $4.1 \%$ \\
\hline MARINE POLICY & $4.1 \%$ \\
\hline ECOLOGY AND SOCIETY & $2.9 \%$ \\
\hline ENVIRONMENTAL MANAGEMENT & $2.9 \%$ \\
\hline ESTUARINE COASTAL AND SHELF SCIENCE & $2.9 \%$ \\
\hline REGIONAL ENVIRONMENTAL CHANGE & $2.4 \%$ \\
\hline ECOLOGICAL ECONOMICS & $1.8 \%$ \\
\hline ENVIRONMENTAL CONSERVATION & $1.8 \%$ \\
\hline GLOBAL ENVIRONMENTAL CHANGE-HUMAN AND POLICY DIMENSIONS & $1.8 \%$ \\
\hline LAND USE POLICY & $1.8 \%$ \\
\hline GEOGRAPHICAL JOURNAL & $1.2 \%$ \\
\hline ECOLOGICAL MODELLING & $1.2 \%$ \\
\hline ENVIRONMENTAL MONITORING AND ASSESSMENT & $1.2 \%$ \\
\hline ENVIRONMENTAL SCIENCE \& POLICY & $1.2 \%$ \\
\hline FISHERIES RESEARCH & $1.2 \%$ \\
\hline INTERNATIONAL JOURNAL OF ENVIRONMENTAL RESEARCH & $1.2 \%$ \\
\hline MARINE POLLUTION BULLETIN & $1.2 \%$ \\
\hline AFRICAN JOURNAL OF MARINE SCIENCE & $0.6 \%$ \\
\hline APPLIED GEOGRAPHY & $0.6 \%$ \\
\hline BRAZILIAN ARCHIVES OF BIOLOGY AND TECHNOLOGY & $0.6 \%$ \\
\hline CHEMISTRY AND ECOLOGY & $0.6 \%$ \\
\hline CHINA ECONOMIC REVIEW & $0.6 \%$ \\
\hline CITIES & $0.6 \%$ \\
\hline CLIMATE RESEARCH & $0.6 \%$ \\
\hline CLIMATIC CHANGE & $0.6 \%$ \\
\hline COASTAL ENGINEERING & $0.6 \%$ \\
\hline CORAL REEFS & $0.6 \%$ \\
\hline ECOLOGICAL INDICATORS & $0.6 \%$ \\
\hline ENVIRONMENTAL GEOLOGY & $0.6 \%$ \\
\hline ENVIRONMENTAL POLICY AND GOVERNANCE & $0.6 \%$ \\
\hline FISHERIES MANAGEMENT AND ECOLOGY & $0.6 \%$ \\
\hline ICES JOURNAL OF MARINE SCIENCE & $0.6 \%$ \\
\hline INTERNATIONAL JOURNAL OF GEOGRAPHICAL INFORMATION SCIENCE & $0.6 \%$ \\
\hline INTERNATIONAL JOURNAL OF SUSTAINABLE DEVELOPMENT AND WORLD ECOLOGY & $0.6 \%$ \\
\hline JOURNAL OF COASTAL CONSERVATION & $0.6 \%$ \\
\hline JOURNAL OF HAZARDOUS MATERIALS & $0.6 \%$ \\
\hline MARINE ECOLOGY PROGRESS SERIES & $0.6 \%$ \\
\hline OCEAN ENGINEERING & $0.6 \%$ \\
\hline PHILIPPINE AGRICULTURAL SCIENTIST & $0.6 \%$ \\
\hline RISK ANALYSIS & $0.6 \%$ \\
\hline SCIENCE OF THE TOTAL ENVIRONMENT & $0.6 \%$ \\
\hline SCOTTISH GEOGRAPHICAL JOURNAL & $0.6 \%$ \\
\hline SOCIETY \& NATURAL RESOURCES & $0.6 \%$ \\
\hline TOURISM MANAGEMENT & $0.6 \%$ \\
\hline WATER AND ENVIRONMENT JOURNAL & $0.6 \%$ \\
\hline WATER RESOURCES MANAGEMENT & $0.6 \%$ \\
\hline Total & $100 \%$ \\
\hline
\end{tabular}

\subsubsection{Journals}

\begin{tabular}{|l|r|r|r|c|}
\cline { 2 - 5 } \multicolumn{1}{c|}{} & CZM journals & Marine sciences & Other journals & Total \\
\hline Sample $(\mathrm{n}=170)$ & $53.5 \%$ & $8.2 \%$ & $38.2 \%$ & $100.0 \%$ \\
Population $(\mathrm{n}=1681)$ & $51.8 \%$ & $13.0 \%$ & $35.2 \%$ & $100.0 \%$ \\
\hline
\end{tabular}




\subsubsection{Parts of the world (case studies)}

\begin{tabular}{|l|r|r|}
\hline Northwestern Europe & Sample $\left(\mathrm{n}=171^{*}\right)$ & Population $\left(\mathrm{n}=1533^{*}\right)$ \\
Asia & $33.9 \%$ & $29.7 \%$ \\
Southeastern Europe (inc. Mediterranean and Black Seas) & $12.3 \%$ \\
South America (inc. Caribbean Sea and Gulf of Mexico) & $17.5 \%$ & $11.0 \%$ \\
Africa & $12.3 \%$ & $12.2 \%$ \\
Middle East and Indian subcontinent & $5.3 \%$ & $5.9 \%$ \\
Australasia, Pacific islands & $4.1 \%$ & $7.5 \%$ \\
North America & $3.5 \%$ & $7.6 \%$ \\
\hline Total & $3.5 \%$ & $13.8 \%$ \\
\hline
\end{tabular}

*Number of case studies per region

\subsubsection{Disciplinary approach}

\begin{tabular}{|c|c|}
\hline $\begin{array}{l}\text { Interdisciplinary approaches } \\
\text { Mono-disciplinary approaches }\end{array}$ & $\begin{array}{l}54.7 \% \\
45.3 \% \\
\end{array}$ \\
\hline Total & $100.0 \%$ \\
\hline
\end{tabular}

Note: Interdisciplinary approaches simultaneously use information on social systems and morpho-ecological systems.

3.2. Emerging and declining conceptual/analytical frameworks (total number of papers, $n=170$ )

\begin{tabular}{|c|c|c|c|c|c|c|c|c|c|c|}
\hline & Integration & Sustainability & $\begin{array}{l}\text { Perceptions, } \\
\text { opinions }\end{array}$ & Value & $\begin{array}{l}\text { Preferences, } \\
\text { choices, } \\
\text { alternatives }\end{array}$ & Participation & $\begin{array}{l}\text { Ecosystem } \\
\text { services }\end{array}$ & $\begin{array}{c}\text { Vulnerability, } \\
\text { risk }\end{array}$ & $\begin{array}{l}\text { DPSIR, } \\
\text { PSR }\end{array}$ & $\begin{array}{l}\text { Carrying } \\
\text { capacity }\end{array}$ \\
\hline Frequency (1992-2011) & $49 \%$ & $33 \%$ & $30 \%$ & $26 \%$ & $25 \%$ & $23 \%$ & $11 \%$ & $10 \%$ & $9 \%$ & $4 \%$ \\
\hline T1. 1992-2001 & $38 \%$ & $8 \%$ & $38 \%$ & $29 \%$ & $25 \%$ & $13 \%$ & $4 \%$ & $17 \%$ & $4 \%$ & $4 \%$ \\
\hline T2. 2002-2006 & $62 \%$ & $45 \%$ & $31 \%$ & $21 \%$ & $26 \%$ & $21 \%$ & $5 \%$ & $2 \%$ & $10 \%$ & $0 \%$ \\
\hline T3. 2002-2011 & $47 \%$ & $33 \%$ & $28 \%$ & $28 \%$ & $25 \%$ & $26 \%$ & $14 \%$ & $13 \%$ & $10 \%$ & $6 \%$ \\
\hline $\mathrm{T} 2$ - $\mathrm{T} 1$ & $24 \%$ & $37 \%$ & $-7 \%$ & $-8 \%$ & $1 \%$ & $9 \%$ & $1 \%$ & $-14 \%$ & $5 \%$ & $-4 \%$ \\
\hline T3 - T2 & $-15 \%$ & $-13 \%$ & $-3 \%$ & $6 \%$ & $-1 \%$ & $5 \%$ & $10 \%$ & $10 \%$ & $0 \%$ & $6 \%$ \\
\hline $\mathrm{T} 3-\mathrm{T} 1$ & $10 \%$ & $24 \%$ & $-10 \%$ & $-1 \%$ & $0 \%$ & $13 \%$ & $10 \%$ & $-4 \%$ & $5 \%$ & $2 \%$ \\
\hline $\begin{array}{l}\text { Difference }(\mathrm{T} 1 \neq \mathrm{T} 2) \\
\text { Fisher's exact test } \\
P \text {-value }\end{array}$ & .049 & .002 & .390 & .338 & .579 & .289 & .702 & .055 & .396 & .364 \\
\hline $\begin{array}{l}\text { Difference }(\mathrm{T} 2 \neq \mathrm{T} 3) \\
\text { Fisher's exact test } \\
P \text {-value }\end{array}$ & .075 & .109 & .428 & .279 & .518 & .364 & .081 & .049 & .628 & .125 \\
\hline $\begin{array}{l}\text { Difference }(\mathrm{T} 1 \neq \mathrm{T} 3) \\
\text { Fisher's exact test } \\
P \text {-value }\end{array}$ & .267 & .011 & .244 & .541 & .593 & .126 & .151 & .398 & .349 & .610 \\
\hline
\end{tabular}


3.3. Socio-economic information: detailed classification (expressed as a percentage of the total number of papers, $n=170$ )

\begin{tabular}{|lr|lr|}
\hline Socio-economic information & Frequency & Socio-economic information & Frequency \\
\hline Coastal population & $66 \%$ & Demographic & $47 \%$ \\
& & Livelihood & $36 \%$ \\
\hline Coastal use intensity & $62 \%$ & \\
\hline Opinion, preference & $61 \%$ & Responses (alternatives, perceived impacts) & $39 \%$ \\
& & Main concerns & $36 \%$ \\
\hline Economic value & $53 \%$ & Coastal activities & $29 \%$ \\
& & Amenities & $19 \%$ \\
& & Ecosystem services & $14 \%$ \\
\hline Coastal activities & $52 \%$ & Economic value & $29 \%$ \\
\hline Response, management & $52 \%$ & Management costs & $29 \%$ \\
& & Other information (other than opinions, preferences) & $31 \%$ \\
\hline
\end{tabular}

3.4. Socio-economic information: combinations (total number of papers, $n=170$ )

\begin{tabular}{|c|c|c|c|c|c|c|c|}
\hline $\begin{array}{c}\text { Coastal } \\
\text { population }\end{array}$ & $\begin{array}{l}\text { Coastal use } \\
\text { intensity }\end{array}$ & $\begin{array}{l}\text { Opinions, } \\
\text { preferences }\end{array}$ & $\begin{array}{c}\text { Economic } \\
\text { value }\end{array}$ & $\begin{array}{c}\text { Coastal } \\
\text { activities }\end{array}$ & $\begin{array}{l}\text { Response, } \\
\text { management }\end{array}$ & $\begin{array}{c}\text { Socio-economic } \\
\text { information } \\
\text { (total) }\end{array}$ & $\%$ papers \\
\hline 1 & 1 & 0 & 1 & 1 & 0 & 4 & $10.0 \%$ \\
\hline 1 & 1 & 0 & 1 & 1 & 1 & 5 & $7.6 \%$ \\
\hline 0 & 0 & 1 & 0 & 0 & 1 & 2 & $7.1 \%$ \\
\hline 1 & 0 & 1 & 0 & 0 & 0 & 2 & $5.9 \%$ \\
\hline 1 & 1 & 1 & 1 & 1 & 1 & 6 & $5.3 \%$ \\
\hline 1 & 1 & 1 & 0 & 1 & 0 & 4 & $5.3 \%$ \\
\hline 1 & 1 & 1 & 0 & 0 & 0 & 3 & $5.3 \%$ \\
\hline 1 & 1 & 1 & 0 & 1 & 1 & 5 & $4.7 \%$ \\
\hline 1 & 0 & 1 & 0 & 0 & 1 & 3 & $4.1 \%$ \\
\hline 0 & 1 & 0 & 1 & 1 & 1 & 4 & $3.5 \%$ \\
\hline 0 & 0 & 0 & 1 & 0 & 1 & 2 & $3.5 \%$ \\
\hline 0 & 0 & 1 & 0 & 0 & 0 & 1 & $3.5 \%$ \\
\hline 0 & 0 & 1 & 1 & 0 & 1 & 3 & $2.9 \%$ \\
\hline 0 & 1 & 0 & 1 & 1 & 0 & 3 & $2.9 \%$ \\
\hline 1 & 1 & 1 & 1 & 1 & 0 & 5 & $2.4 \%$ \\
\hline 1 & 1 & 1 & 0 & 0 & 1 & 4 & $2.4 \%$ \\
\hline 0 & 0 & 0 & 1 & 0 & 0 & 1 & $2.4 \%$ \\
\hline 1 & 1 & 1 & 1 & 0 & 1 & 5 & $1.8 \%$ \\
\hline 1 & 0 & 1 & 1 & 0 & 1 & 4 & $1.8 \%$ \\
\hline 0 & 0 & 0 & 1 & 1 & 1 & 3 & $1.8 \%$ \\
\hline 1 & 1 & 0 & 0 & 0 & 0 & 2 & $1.8 \%$ \\
\hline 0 & 1 & 1 & 0 & 1 & 1 & 4 & $1.2 \%$ \\
\hline 1 & 1 & 1 & 1 & 0 & 0 & 4 & $1.2 \%$ \\
\hline 0 & 1 & 1 & 0 & 1 & 0 & 3 & $1.2 \%$ \\
\hline 1 & 0 & 1 & 1 & 0 & 0 & 3 & $1.2 \%$ \\
\hline 1 & 1 & 0 & 0 & 1 & 0 & 3 & $1.2 \%$ \\
\hline 1 & 0 & 0 & 1 & 0 & 0 & 2 & $1.2 \%$ \\
\hline 0 & 1 & 1 & 1 & 1 & 1 & 5 & $0.6 \%$ \\
\hline 0 & 0 & 1 & 1 & 1 & 1 & 4 & $0.6 \%$ \\
\hline 0 & 1 & 1 & 1 & 1 & 0 & 4 & $0.6 \%$ \\
\hline 1 & 0 & 1 & 0 & 1 & 1 & 4 & $0.6 \%$ \\
\hline 1 & 1 & 0 & 0 & 1 & 1 & 4 & $0.6 \%$ \\
\hline 0 & 0 & 1 & 0 & 1 & 1 & 3 & $0.6 \%$ \\
\hline 0 & 1 & 0 & 0 & 1 & 1 & 3 & $0.6 \%$ \\
\hline 1 & 0 & 0 & 1 & 0 & 1 & 3 & $0.6 \%$ \\
\hline 1 & 1 & 0 & 0 & 0 & 1 & 3 & $0.6 \%$ \\
\hline 1 & 1 & 0 & 1 & 0 & 0 & 3 & $0.6 \%$ \\
\hline 0 & 0 & 1 & 0 & 1 & 0 & 2 & $0.6 \%$ \\
\hline 0 & 1 & 0 & 0 & 1 & 0 & 2 & $0.6 \%$ \\
\hline
\end{tabular}


3.5. Tools, methodologies: combinations (total number of papers, $n=170$ )

\begin{tabular}{|c|c|c|c|c|c|c|c|c|c|c|c|}
\hline Survey & $\begin{array}{l}\text { Monetary } \\
\text { valuation }\end{array}$ & $\begin{array}{l}\text { Spatial data } \\
\text { analysis }\end{array}$ & $\begin{array}{l}\text { Trends } \\
\text { analysis }\end{array}$ & $\begin{array}{c}\text { Scenario, } \\
\text { prospective }\end{array}$ & $\begin{array}{c}\text { Explanatory } \\
\text { modelling }\end{array}$ & $\begin{array}{l}\text { Indicators } \\
\text { system }\end{array}$ & $\begin{array}{c}\text { CBA or } \\
\text { CEA }\end{array}$ & MCA & $\begin{array}{l}\text { Participatory } \\
\text { approaches }\end{array}$ & $\begin{array}{c}\text { Tools, } \\
\text { methods (total) }\end{array}$ & $\begin{array}{c}\% \\
\text { papers }\end{array}$ \\
\hline 1 & 0 & 0 & 0 & 0 & 0 & 0 & 0 & 0 & 0 & 1 & $9.9 \%$ \\
\hline 1 & 0 & 1 & 0 & 0 & 0 & 0 & 0 & 0 & 0 & 2 & $5.8 \%$ \\
\hline 1 & 0 & 0 & 1 & 0 & 0 & 0 & 0 & 0 & 0 & 2 & $4.7 \%$ \\
\hline 1 & 1 & 0 & 0 & 0 & 0 & 0 & 0 & 0 & 0 & 2 & $4.7 \%$ \\
\hline 0 & 1 & 1 & 1 & 1 & 0 & 0 & 1 & 0 & 0 & 5 & $4.1 \%$ \\
\hline 0 & 1 & 1 & 1 & 1 & 0 & 0 & 0 & 0 & 0 & 4 & $3.5 \%$ \\
\hline 1 & 0 & 0 & 0 & 1 & 1 & 0 & 0 & 0 & 0 & 3 & $3.5 \%$ \\
\hline 0 & 1 & 1 & 1 & 1 & 0 & 1 & 0 & 0 & 0 & 5 & $2.3 \%$ \\
\hline 0 & 1 & 1 & 0 & 0 & 0 & 1 & 0 & 0 & 0 & 3 & $2.3 \%$ \\
\hline 1 & 0 & 1 & 0 & 0 & 0 & 1 & 0 & 0 & 0 & 3 & $2.3 \%$ \\
\hline 1 & 0 & 1 & 0 & 0 & 1 & 0 & 0 & 0 & 0 & 3 & $2.3 \%$ \\
\hline 1 & 1 & 0 & 0 & 1 & 0 & 0 & 0 & 0 & 0 & 3 & $2.3 \%$ \\
\hline 1 & 0 & 0 & 0 & 0 & 1 & 0 & 0 & 0 & 0 & 2 & $2.3 \%$ \\
\hline 0 & 1 & 0 & 1 & 1 & 0 & 0 & 1 & 0 & 0 & 4 & $1.8 \%$ \\
\hline 1 & 1 & 0 & 0 & 1 & 1 & 0 & 0 & 0 & 0 & 4 & $1.8 \%$ \\
\hline 1 & 0 & 1 & 1 & 0 & 0 & 0 & 0 & 0 & 0 & 3 & $1.8 \%$ \\
\hline 1 & 1 & 0 & 0 & 0 & 1 & 0 & 0 & 0 & 0 & 3 & $1.8 \%$ \\
\hline 1 & 1 & 0 & 1 & 0 & 0 & 0 & 0 & 0 & 0 & 3 & $1.8 \%$ \\
\hline 1 & 0 & 0 & 0 & 0 & 0 & 0 & 0 & 0 & 1 & 2 & $1.8 \%$ \\
\hline 1 & 1 & 0 & 1 & 1 & 0 & 0 & 0 & 1 & 1 & 6 & $1.2 \%$ \\
\hline 1 & 1 & 0 & 1 & 1 & 0 & 0 & 0 & 0 & 1 & 5 & $1.2 \%$ \\
\hline 1 & 1 & 1 & 0 & 0 & 1 & 1 & 0 & 0 & 0 & 5 & $1.2 \%$ \\
\hline 0 & 1 & 1 & 1 & 0 & 0 & 1 & 0 & 0 & 0 & 4 & $1.2 \%$ \\
\hline 0 & 1 & 0 & 1 & 0 & 0 & 0 & 1 & 0 & 0 & 3 & $1.2 \%$ \\
\hline 1 & 0 & 0 & 0 & 1 & 0 & 0 & 0 & 0 & 1 & 3 & $1.2 \%$ \\
\hline 1 & 0 & 0 & 1 & 0 & 0 & 1 & 0 & 0 & 0 & 3 & $1.2 \%$ \\
\hline 1 & 1 & 1 & 0 & 0 & 0 & 0 & 0 & 0 & 0 & 3 & $1.2 \%$ \\
\hline 0 & 0 & 1 & 0 & 0 & 0 & 1 & 0 & 0 & 0 & 2 & $1.2 \%$ \\
\hline 0 & 1 & 1 & 1 & 1 & 0 & 1 & 1 & 1 & 0 & 7 & $0.6 \%$ \\
\hline 0 & 1 & 1 & 1 & 1 & 1 & 1 & 1 & 0 & 0 & 7 & $0.6 \%$ \\
\hline 1 & 1 & 1 & 1 & 1 & 0 & 0 & 1 & 0 & 1 & 7 & $0.6 \%$ \\
\hline 0 & 1 & 1 & 1 & 1 & 0 & 1 & 0 & 1 & 0 & 6 & $0.6 \%$ \\
\hline 1 & 1 & 0 & 0 & 1 & 1 & 0 & 0 & 1 & 1 & 6 & $0.6 \%$ \\
\hline 1 & 1 & 0 & 1 & 1 & 0 & 0 & 1 & 1 & 0 & 6 & $0.6 \%$ \\
\hline 1 & 1 & 1 & 1 & 1 & 0 & 0 & 1 & 0 & 0 & 6 & $0.6 \%$ \\
\hline 1 & 1 & 1 & 1 & 0 & 1 & 1 & 0 & 0 & 0 & 6 & $0.6 \%$ \\
\hline 0 & 1 & 1 & 0 & 0 & 1 & 1 & 0 & 1 & 0 & 5 & $0.6 \%$ \\
\hline 0 & 1 & 1 & 0 & 1 & 1 & 1 & 0 & 0 & 0 & 5 & $0.6 \%$ \\
\hline 0 & 1 & 1 & 1 & 1 & 0 & 0 & 0 & 1 & 0 & 5 & $0.6 \%$ \\
\hline 1 & 0 & 0 & 0 & 1 & 0 & 1 & 0 & 1 & 1 & 5 & $0.6 \%$ \\
\hline 1 & 0 & 0 & 1 & 1 & 0 & 0 & 0 & 1 & 1 & 5 & $0.6 \%$ \\
\hline 1 & 0 & 1 & 1 & 0 & 0 & 1 & 0 & 1 & 0 & 5 & $0.6 \%$ \\
\hline 1 & 1 & 0 & 0 & 1 & 0 & 0 & 1 & 0 & 1 & 5 & $0.6 \%$ \\
\hline 1 & 1 & 0 & 0 & 1 & 1 & 0 & 0 & 1 & 0 & 5 & $0.6 \%$ \\
\hline 1 & 1 & 0 & 1 & 1 & 0 & 0 & 0 & 1 & 0 & 5 & $0.6 \%$ \\
\hline 1 & 1 & 0 & 1 & 1 & 0 & 0 & 1 & 0 & 0 & 5 & $0.6 \%$ \\
\hline 1 & 1 & 1 & 0 & 1 & 0 & 0 & 1 & 0 & 0 & 5 & $0.6 \%$ \\
\hline 1 & 1 & 1 & 0 & 1 & 0 & 1 & 0 & 0 & 0 & 5 & $0.6 \%$ \\
\hline 1 & 1 & 1 & 0 & 1 & 1 & 0 & 0 & 0 & 0 & 5 & $0.6 \%$ \\
\hline 1 & 1 & 1 & 1 & 1 & 0 & 0 & 0 & 0 & 0 & 5 & $0.6 \%$ \\
\hline 0 & 1 & 1 & 0 & 0 & 1 & 1 & 0 & 0 & 0 & 4 & $0.6 \%$ \\
\hline 0 & 1 & 1 & 1 & 0 & 0 & 0 & 1 & 0 & 0 & 4 & $0.6 \%$ \\
\hline 0 & 1 & 1 & 1 & 0 & 1 & 0 & 0 & 0 & 0 & 4 & $0.6 \%$ \\
\hline 1 & 0 & 0 & 1 & 1 & 0 & 0 & 0 & 0 & 1 & 4 & $0.6 \%$ \\
\hline 1 & 0 & 0 & 1 & 0 & 1 & 1 & 0 & 0 & 0 & 4 & $0.6 \%$ \\
\hline 1 & 0 & 1 & 1 & 1 & 0 & 0 & 0 & 0 & 0 & 4 & $0.6 \%$ \\
\hline 1 & 1 & 0 & 1 & 0 & 0 & 0 & 1 & 0 & 0 & 4 & $0.6 \%$ \\
\hline 1 & 1 & 1 & 0 & 0 & 0 & 1 & 0 & 0 & 0 & 4 & $0.6 \%$ \\
\hline
\end{tabular}




\begin{tabular}{|llllllllll|l|l|}
0 & 1 & 0 & 1 & 1 & 0 & 0 & 0 & 0 & 0 & 3 & $0.6 \%$ \\
0 & 1 & 0 & 1 & 0 & 0 & 1 & 0 & 0 & 0 & 3 & $0.6 \%$ \\
0 & 1 & 0 & 1 & 0 & 1 & 0 & 0 & 0 & 0 & 3 & $0.6 \%$ \\
0 & 1 & 1 & 0 & 0 & 1 & 0 & 0 & 0 & 0 & 3 & $0.6 \%$ \\
0 & 1 & 1 & 1 & 0 & 0 & 0 & 0 & 0 & 0 & 3 & $0.6 \%$ \\
1 & 0 & 0 & 0 & 0 & 1 & 0 & 0 & 0 & 1 & 3 & $0.6 \%$ \\
1 & 0 & 0 & 0 & 0 & 1 & 1 & 0 & 0 & 0 & 3 & $0.6 \%$ \\
1 & 0 & 0 & 1 & 0 & 1 & 0 & 0 & 0 & 0 & 3 & $0.6 \%$ \\
1 & 0 & 1 & 0 & 1 & 0 & 0 & 0 & 0 & 0 & 3 & $0.6 \%$ \\
1 & 1 & 0 & 0 & 0 & 0 & 0 & 1 & 0 & 0 & 3 & $0.6 \%$ \\
0 & 0 & 0 & 0 & 1 & 0 & 0 & 0 & 1 & 0 & 2 & $0.6 \%$ \\
0 & 0 & 0 & 1 & 0 & 0 & 1 & 0 & 0 & 0 & 2 & $0.6 \%$ \\
0 & 0 & 1 & 1 & 0 & 0 & 0 & 0 & 0 & 0 & 2 & $0.6 \%$ \\
0 & 1 & 0 & 0 & 0 & 0 & 0 & 1 & 0 & 0 & 2 & $0.6 \%$ \\
0 & 1 & 1 & 0 & 0 & 0 & 0 & 0 & 0 & 0 & 2 & $0.6 \%$ \\
1 & 0 & 0 & 0 & 0 & 0 & 0 & 0 & 1 & 0 & 2 & $0.6 \%$ \\
0 & 0 & 0 & 0 & 0 & 0 & 1 & 0 & 0 & 0 & 1 & $0.6 \%$ \\
0 & 1 & 0 & 0 & 0 & 0 & 0 & 0 & 0 & 0 & \\
\hline
\end{tabular}

3.6. Coastal issues and coastal interactions classified by level of economic development (total number of papers, $n=170$ )

A) Coastal issues classified by level of economic development

\begin{tabular}{|l|c|c|c|c|}
\cline { 2 - 5 } \multicolumn{1}{c|}{} & $\begin{array}{c}\text { Coastal amenities, } \\
\text { welfare }\end{array}$ & $\begin{array}{c}\text { Coastal economy, } \\
\text { livelihood }\end{array}$ & $\begin{array}{c}\text { Environmental } \\
\text { degradation }\end{array}$ & Coastal hazards \\
\hline a) Low and middle income $(n=68)$ & $22 \%$ & $79 \%$ & $78 \%$ & $21 \%$ \\
b) High income $(n=102)$ & $62 \%$ & $53 \%$ & $62 \%$ & $41 \%$ \\
\hline b - a & $40 \%$ & $-26 \%$ & $-16 \%$ & $21 \%$ \\
\hline Total $(n=170)$ & $46 \%$ & $64 \%$ & $69 \%$ & $34 \%$ \\
\hline$\chi 2$ & 25.9 & 12.3 & 4.9 & 7.8 \\
D.f. & 1 & 1 & 1 & .026 \\
$P$-value & .000 & .000 & & .005 \\
\hline Fisher's exact test & & & .0019 & .004 \\
$P$-value & .000 & .000 & & \\
\hline
\end{tabular}

B) Coastal interactions classified by level of economic development

\begin{tabular}{|l|c|c|c|c|}
\cline { 2 - 5 } \multicolumn{1}{c|}{} & $\begin{array}{c}\text { SOC pressures / } \\
\text { SOC impacts }\end{array}$ & $\begin{array}{c}\text { SOC pressures / } \\
\text { ECO states }\end{array}$ & $\begin{array}{c}\text { ECO states / } \\
\text { SOC impacts }\end{array}$ & $\begin{array}{c}\text { SOC / ECO and } \\
\text { ECO / SOC }\end{array}$ \\
\hline a) Low and middle income $(n=67)$ & $4 \%$ & $12 \%$ & $51 \%$ & $34 \%$ \\
b) High income $(n=98)$ & $11 \%$ & $13 \%$ & $50 \%$ & $31 \%$ \\
\hline b-a & $7 \%$ & $1 \%$ & $-1 \%$ & $-4 \%$ \\
\hline Total $(n=165)$ & $8 \%$ & $13 \%$ & $50 \%$ & $32 \%$ \\
\hline$\chi 2$ & 2.3 & 0.1 & 0.0 & 0.3 \\
D.f. & 1 & 1 & 1 & .61 \\
$P$-value & .127 & .802 & .925 & .369 \\
\hline Fisher's exact test & & & .526 & .369 \\
$P$-value & .105 & .499 & & \\
\hline
\end{tabular}


3.7. Socio-economic information classified by the goals of the socio-economic assessments (total number of papers, $n=170$ )

\begin{tabular}{|l|c|c|c|ccc|}
\cline { 2 - 6 } \multicolumn{1}{c|}{} & $\begin{array}{c}\text { Problem definition } \\
(n=66)\end{array}$ & $\begin{array}{c}\text { Management options } \\
(n=68)\end{array}$ & $\begin{array}{c}\text { Response impacts } \\
(n=36)\end{array}$ & $\chi 2$ & D.f. & $P$-value \\
\hline Coastal population & $77 \%$ & $57 \%$ & $64 \%$ & 6.1 & 2 & .047 \\
Coastal use intensity & $73 \%$ & $62 \%$ & $42 \%$ & 9.5 & 2 & .009 \\
Opinion, preference & $45 \%$ & $66 \%$ & $78 \%$ & 11.7 & 2 & .003 \\
Economic value & $48 \%$ & $63 \%$ & $42 \%$ & 5.3 & 2 & .072 \\
Coastal activities & $58 \%$ & $56 \%$ & $36 \%$ & 4.9 & 2 & .088 \\
Response & $20 \%$ & $74 \%$ & $72 \%$ & 46.1 & 2 & .000 \\
\hline
\end{tabular}

3.8. Tools and methodologies classified by the goals of the socio-economic assessments (total number of papers, $n=170$ )

\begin{tabular}{|c|c|c|c|c|c|c|c|}
\hline & $\begin{array}{c}\text { Problem definition } \\
\quad(n=66)\end{array}$ & $\begin{array}{c}\text { Management } \\
\text { options }(n=68)\end{array}$ & $\begin{array}{c}\text { Response impacts } \\
(n=36)\end{array}$ & $\chi^{2}$ & $\begin{array}{c}\text { Fisher's exact } \\
\text { test }\end{array}$ & D.f. & $P$-value \\
\hline Survey & $62 \%$ & $69 \%$ & $86 \%$ & 6.4 & Not relevant & 2 & .040 \\
\hline Monetary valuation & $48 \%$ & $63 \%$ & $42 \%$ & 5.3 & Not relevant & 2 & .072 \\
\hline Spatial data analysis & $65 \%$ & $34 \%$ & $22 \%$ & 21.8 & Not relevant & 2 & .000 \\
\hline Trends analysis & $26 \%$ & $47 \%$ & $58 \%$ & 11.8 & Not relevant & 2 & .003 \\
\hline Scenarios, prospective & $0 \%$ & $74 \%$ & $0 \%$ & 106.3 & Not relevant & 2 & .000 \\
\hline Explanatory modelling & $27 \%$ & $19 \%$ & $17 \%$ & 2.0 & Not relevant & 2 & .367 \\
\hline Indicators system & $41 \%$ & $9 \%$ & $8 \%$ & 25.2 & Not relevant & 2 & .000 \\
\hline CBA or CEA & $0 \%$ & $25 \%$ & $19 \%$ & 18.3 & Not relevant & 2 & .000 \\
\hline Multi-criteria analysis & $0 \%$ & $24 \%$ & $0 \%$ & Not relevant & Relevant & - & $.000-.006$ \\
\hline Participatory approach & $0 \%$ & $16 \%$ & $0 \%$ & Not relevant & Relevant & & $.000-.001$ \\
\hline
\end{tabular}

